\title{
A COMPARISON OF MEAT PURCHASING ATTITUDES ACROSS GENERATIONS
}

\author{
A Thesis \\ presented to \\ the Faculty of California Polytechnic State University, \\ San Luis Obispo
}

\begin{abstract}
In Partial Fulfillment
of the Requirements for the Degree

Master of Science in Agribusiness
\end{abstract}

By

Jamie Marilyn Mickelson

November 2014 
(C) 2014

Jamie Marilyn Mickelson

ALL RIGHTS RESERVED 
TITLE:

AUTHOR:

DATE SUBMITTED:

COMMITTEE CHAIR:

COMMITTEE MEMBER:

COMMITTEE MEMBER:
A Comparison of Meat Purchasing Attitudes Across Generations

Jamie Marilyn Mickelson

November 2014

Marianne McGarry Wolf, Ph.D.

Professor of Wine and Viticulture

Eivis Qenani, Ph.D.

Professor of Agribusiness

Jaymie Noland, D.V.M

Professor of Animal Science 


\begin{abstract}
A Comparison of Meat Purchasing Attitudes Across Generations
\end{abstract}

Jamie Mickelson

To identify the factors that influence generations' meat purchasing behavior. The list of the features for respondents to report are desirable to them when they purchasing meat. The results of features will provide the answer to meat purchasing attitudes across generations, which will help to analyze which features influences generations' purchasing behavior. There were 290 respondents to the survey. The target markets are split to four groups - young Millennials, older Millennials, Generation Xers, and Baby Boomers. The highest desirability that for respondents' decvisions to purchase the meat is good value for the money and second is no hormones added. The organic product is rated the least desirability for young Millennials, Generation Xers, and Baby Boomers. Lastly, the local brand is not important to purchase meat compare to local vegetables and fruit

Keywords: Generations, Local, Meat, Purchasing Attitudes, Consumer Perception, Meat Consumption, Baby Boomer, Generation Xers, and Millennials. 


\section{ACKNOWLEDGMENTS}

What an amazing opportunity I have gotten from California Polytechnic State University. My sincerest appreciation goes out to Dr. Marianne Wolf, Dr. Eivis Qenani, Aaron Lazanoff, and Dr. Jayme Noland for guiding me through my years at Cal Poly. I have learned so much from working at the cattle operation, teaching classes, creating the online replacement heifer sale and help to start the feedlot program. This experience given me the strength and knowledge to be able to start my business in selling a branded beef product. Again, thank you so much for contributing your time toward my graduate education I couldn't have done it, nor enjoyed myself as much, without your help.

Thank you to my family, especially my parents, for helping me to keep my head held high, getting through the tough times, and making me believe in myself. I appreciate that my instructors at Cal Poly believed in me, giving me the opportunity to stay at Cal Poly and gain more experience and further my education and work ability.

Dr. Marianne Wolf, you are the best advisor that I could ever ask for! Thank you for pushing me to work harder on my thesis for the second time. I miss our good conversations about the business industry and I truly appreciation your time helping me with my thesis. Lastly, I have to thank Aaron Lazanoff for convincing me to stay at Cal Poly for another year. It was such a great learn experience. I will miss my time riding in your truck to check the cows and doing chores.

Lastly, my time at Cal Poly has been a wonderful journey and I am very blessed to have this opportunity. Thank you again! 


\section{TABLE OF CONTENTS}

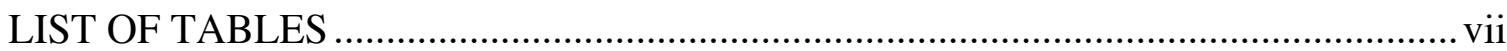

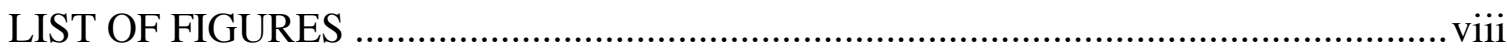

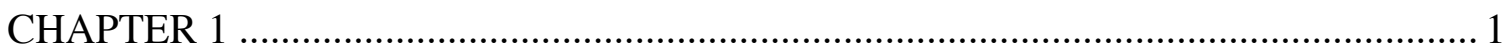

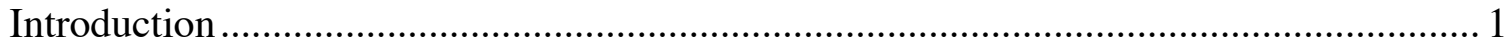

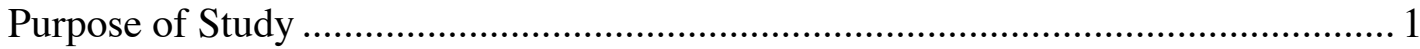

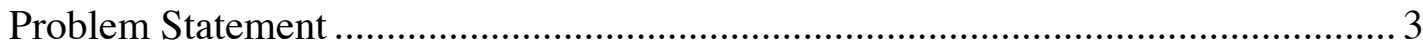

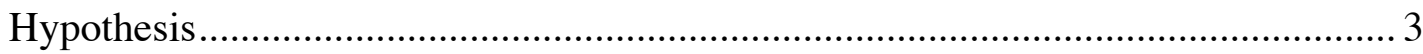

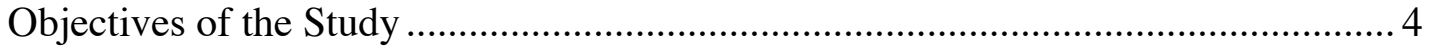

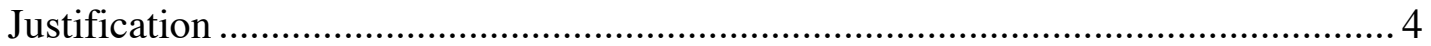

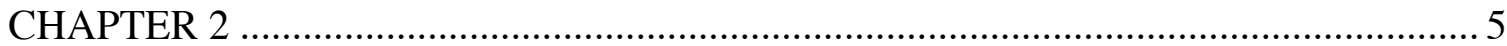

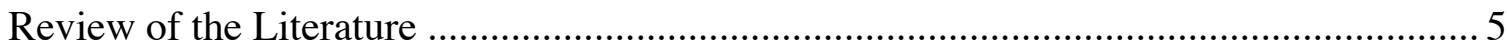

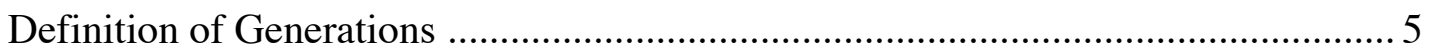

Generations' Education and Work …………………........................................... 7

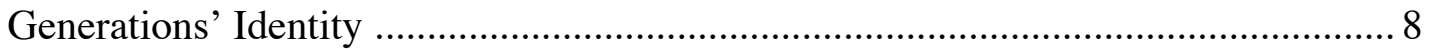

Generational Environmental Behavior .............................................................. 9

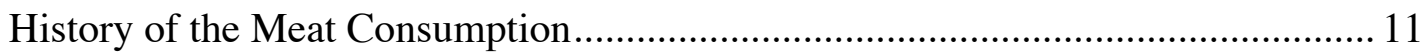

Factors changing the demand for meat ................................................................ 12

Definition of Organic and Natural ...................................................................... 14

Definition of Locally Grown and Farmer Market.................................................... 14

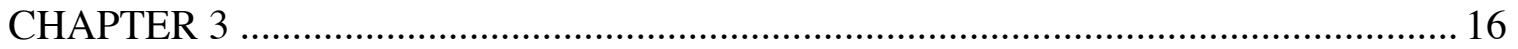

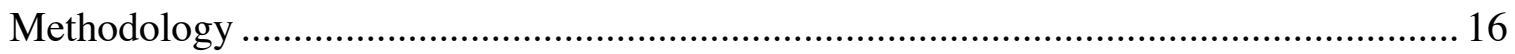

Procedures for Data Collection ......................................................................... 16

Procedures for Data Analysis........................................................................ 18

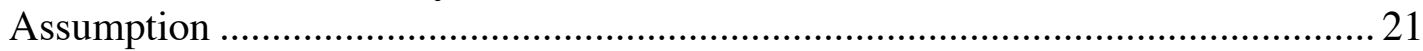

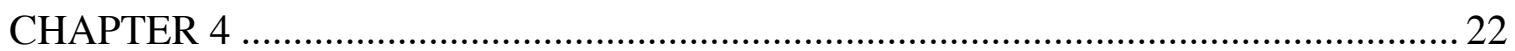

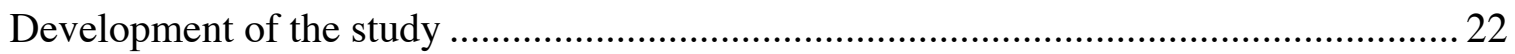

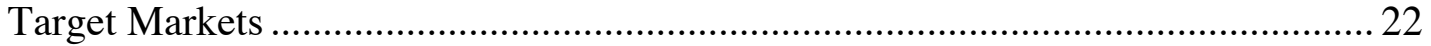

Meat Consumption Behavior ............................................................................. 23

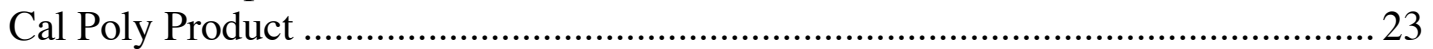

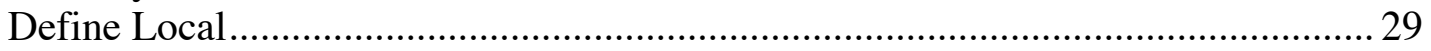

Attitudes toward Cal Poly Meat.......................................................................... 32

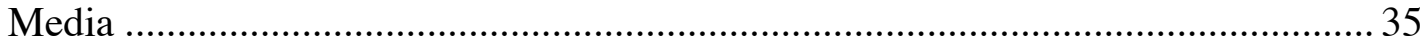

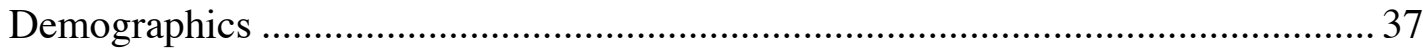

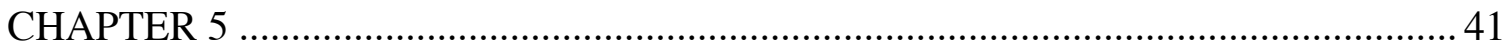

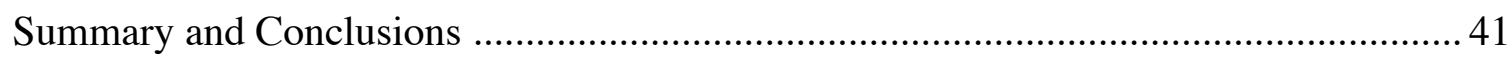

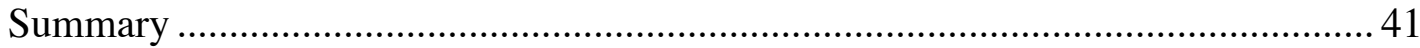

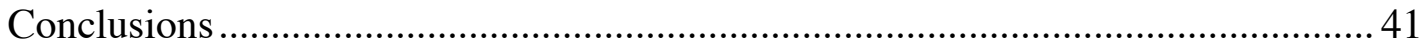

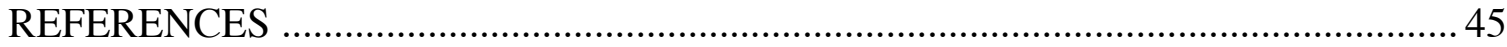

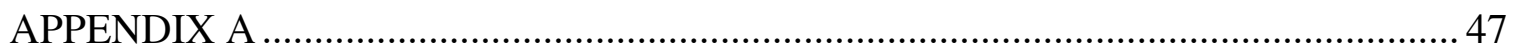




\section{LIST OF TABLES}

Table 1-1: Age of Reference Person ................................................................................ 2

Table 1-2: Percent of dollars allocated to each meat ........................................................ 2

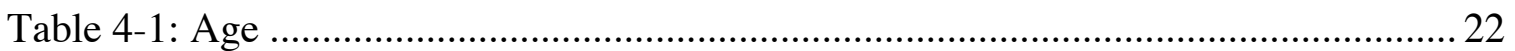

Table 4-2: Which meat products have they purchased for consumption at home in the previous year ........................................................................................................ 23

Table 4-3: Purchased any of the Cal Poly brand food or wine products ......................... 24

Table 4-4: Rate Cal Poly brand food and wine products ............................................. 25

Table 4-5: Where have you purchased your meat products ........................................ 26

Table 4-6: How much money do you spend in a typical month on meat products........... 26

Table 4-7: How much money do you spend in a typical month on total meat products .. 27

Table 4-8: Of the number of times that you serve beef in a month, what percent is ground beef?.

Table 4-9: Of the number of times that you serve beef in a month, what percent is

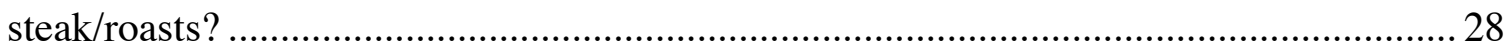

Table 4-10: Rate the desirability of each feature to you when you purchase meat ..........29

Table 4-11: Currently involved in local food initiatives ................................................. 29

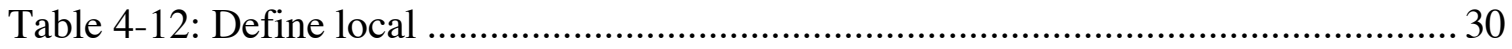

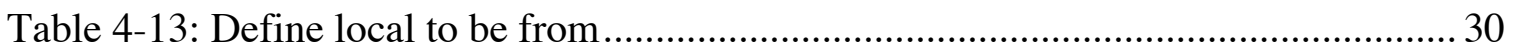

Table 4-14: Which mileage or locality mean what local is ......................................... 31

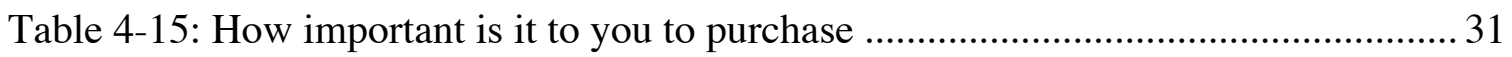

Table 4-16: How likely would you be purchase them in the next year ............................ 33

Table 4-17: Is the price of the Cal Poly Meat products? ............................................. 33

Table 4-18: How likely are you to purchase a Cal Poly meat product at a local

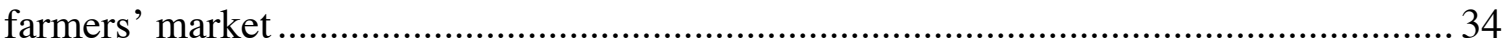

Table 4-19: How likely are you to go to the Cal Poly campus to purchase Cal Poly

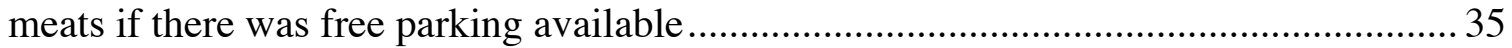

Table 4-20: Which of the following do you use to find information about meat? ........... 36

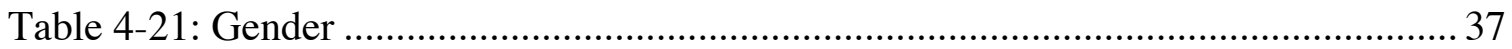

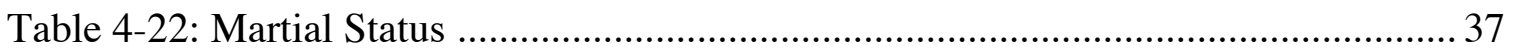

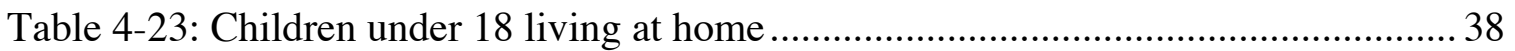

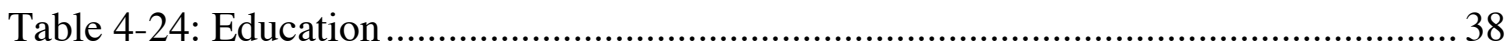

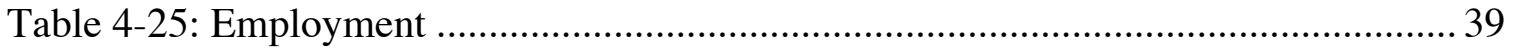

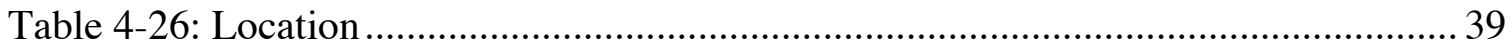

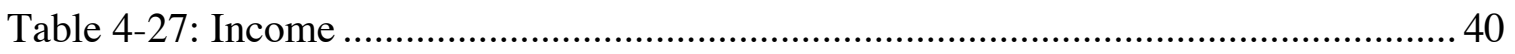




\section{LIST OF FIGURES}

Figure 2-1: Generation Identity .......................................................................... 8

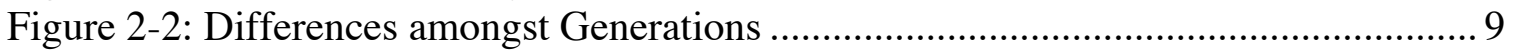

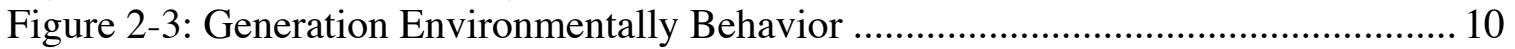

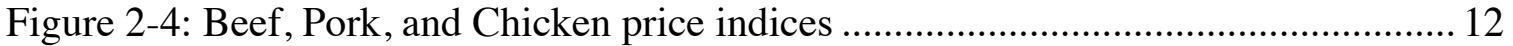

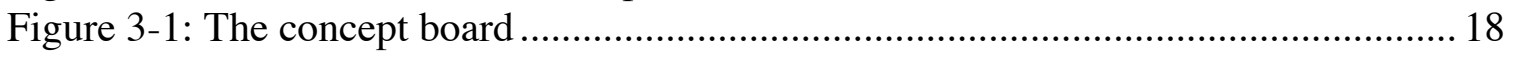

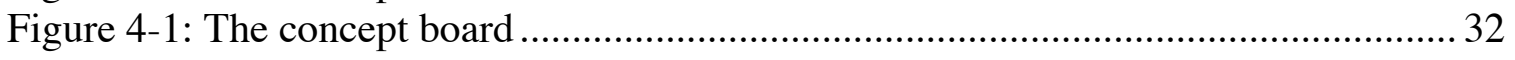




\section{CHAPTER 1}

\section{Introduction}

Technology, culture, social welfare, politics, food consumption, and meat consumption have changed as each decade passes. These changes have affected the consumer's view on everything, including their purchasing attitudes toward meat consumption. Fresh meat consumption today is affected by demand for a healthy and safe product, environmental and ethical concerns, accidents, scandals and product safety incidents that tend to attract negative media attention, changes in consumer tastes and preferences, the economy, as well as product palatability (Brewer, 2008). Changes in consumers' purchasing patterns and attitudes have a direct impact on farmers' and ranchers' operations.

\section{Purpose of Study}

The purpose of this study is to identify the factors that influence generations' meat purchasing behavior. The other purpose of this study is to explore if the changes in technology, culture, social welfare, politics, food consumption, and meat consumption have caused all the generations to have similar meat purchasing attitudes. It is important to analyze the similarities and differences across the generations because in the future, the food preferences and health priorities of older Americans will dominate because of the 
population shift (Brewer, 2008). Gaining a better understanding of the differences between the generations will help the meat industry to follow the younger generation's trends. Ranchers and farmers can make adjustments to their practices to provide the meat in order to meet the consumer demand in the market place.

There are no previous studies that offer valuable information about what different generation's meat purchasing behavior is and what the similarities and differences are between the generations' meat purchasing attitudes and what has influenced their decisions to purchase meat. The data for meat consumption for each age group exists, but there are no studies that attempt to ascertain the factors that influence meat purchasing by consumers (Table 1-1). In the table 1-2, the studies showing the percent of dollars allocated to each meats for comparison with data were analyze.

Table 1-1: Age of Reference Person.

\begin{tabular}{|c|c|c|c|c|c|c|c|c|}
\hline $\begin{array}{c}\text { Average } \\
\text { Annual } \\
\text { Expenditures }\end{array}$ & $\begin{array}{c}\text { All } \\
\text { consumer } \\
\text { units }\end{array}$ & $\begin{array}{c}\text { Under } \\
25 \text { years }\end{array}$ & $\begin{array}{c}25-35 \\
\text { years }\end{array}$ & $\begin{array}{c}35-44 \\
\text { years }\end{array}$ & $\begin{array}{c}45-54 \\
\text { years }\end{array}$ & $\begin{array}{c}55-64 \\
\text { years }\end{array}$ & $\begin{array}{c}65-74 \\
\text { years }\end{array}$ & $\begin{array}{c}75 \text { years } \\
\text { and older }\end{array}$ \\
\hline $\begin{array}{c}\text { Number of } \\
\text { consumer units } \\
\text { (in thousands) }\end{array}$ & 124,416 & 8,159 & 20,112 & 21,598 & 24,624 & 22,770 & 42,147 & 12,161 \\
\hline
\end{tabular}

Source: Bureau of Labor Statistics, 2012.

Table 1-2: Percent of dollars allocated to each

\begin{tabular}{|c|c|c|c|c|c|c|c|c|}
\hline $\begin{array}{c}\text { Average Annual } \\
\text { Expenditures }\end{array}$ & $\begin{array}{c}\text { All } \\
\text { consumer } \\
\text { units }\end{array}$ & $\begin{array}{c}\text { Under } \\
25 \text { years }\end{array}$ & $\begin{array}{c}25-35 \\
\text { years }\end{array}$ & $\begin{array}{c}35-44 \\
\text { years }\end{array}$ & $\begin{array}{c}45-54 \\
\text { years }\end{array}$ & $\begin{array}{c}55-64 \\
\text { years }\end{array}$ & $\begin{array}{c}65-74 \\
\text { years }\end{array}$ & $\begin{array}{c}75 \text { years } \\
\text { and } \\
\text { older }\end{array}$ \\
\hline Beef & $\$ 226$ & $71 \%$ & $85 \%$ & $117 \%$ & $127 \%$ & $107 \%$ & $89 \%$ & $61 \%$ \\
\hline Pork & $\$ 166$ & $66 \%$ & $87 \%$ & $119 \%$ & $117 \%$ & $105 \%$ & $101 \%$ & $62 \%$ \\
\hline Other meats & $\$ 122$ & $63 \%$ & $91 \%$ & $118 \%$ & $118 \%$ & $99 \%$ & $100 \%$ & $69 \%$ \\
\hline Poultry & $\$ 159$ & $72 \%$ & $103 \%$ & $130 \%$ & $130 \%$ & $100 \%$ & $77 \%$ & $58 \%$ \\
\hline
\end{tabular}

Source: Bureau of Labor Statistics, 2012.

Consumers can be "grouped" in a variety of ways, but grouping by age is one of the most common because those in the same age category tend to have a good deal in 
common which reflects the dominant cultural values when they were growing up and entering into early adulthood (Brewer, 2008). In this study, the target markets are divided into four generational groups: baby boomer, generation $\mathrm{X}$, older millennial, and young millennial.

\section{Problem Statement}

It is beneficial to evaluate generational purchase behavior to gain a better understanding to help improve the marketing of the meat products. The results from the survey will help to improve the understanding of what the individual generations' meat purchasing behavior will be. This understanding will assist meat producers in their production decisions.

\section{Hypothesis}

Hypothesis 1: There are significant differences in meat purchasing behavior between generations.

Hypothesis 2. There is significant difference in purchasing behavior between generations on amount of money spend on meat.

Hypothesis 3: There are significant differences in purchasing behavior between generations who purchase local meat.

Hypothesis 4. There is a significant difference between young and old millennials in the factors that influence their decisions to purchase the meat.

Hypothesis 5: There is significant difference in the factors that influence their decisions to purchase the meat between generations. 


\section{Objectives of the Study}

1. To explore the differences in meat purchasing behavior across generations.

2. To explore the similarities in meat purchase behavior across generations.

3. To identify the importance of "local" attribute among generational consumers.

4. To explore if these generations are interested in purchasing farmers' market meat products.

5. To find out the factors that influences their decision to purchase meat.

6. To address how important it is to have local meat source.

7. To discover what media source generations use to get information about meat.

\section{Justification}

While meat consumption continues to grow, it's time to focus on the consumer's meat purchase behavior to gain a better understanding of what factors influence their decisions. It is also important to gain this knowledge of consumer meat purchasing behavior, so that the meat producers can produce more desirable meat to meet consumer needs and demands. The goal of this study is to discover what are the differences across generations' meat buying patterns and to acknowledge the target market for local businesses. Insights gained from this study may contribute to enhance the efficiency of future meat consumption campaigns. 


\section{CHAPTER 2}

\section{Review of the Literature}

The literature review will summarize the information from previous studies to define the Baby Boomers, Generation X, and Millennial generation and provide a better understanding of the factors that influence their purchasing decisions.

\section{Definition of Generations}

Each generation has unique expectations, experiences, generational history, lifestyles, and values that influence their buying behavior (Williams and Page, 2011). There are currently six American generations; Pre-Depression, Depression, Baby Boom, Generation X, Generation Y, and Generation Z. This research will focus on the Baby Boom, Generation X and Millennial generations. Generational history-be it the economy, scientific progress, politics, technology, or social shocks such as assassinations and terrorist attacks has an immense impacts on each generation (William and Page, 2011).

The Baby Boomer label is drawn from the great spike in fertility that began in 1946, right after the end of World War II, and ended almost as abruptly in 1964, around the time the birth control pill went on the market (Pew, 2010). The age range is 50 to 68 years old. Baby boomer attitudes toward the food that they were willing to purchase convenience and spend money to make life easier (Brewer, 2008). Older female baby 
boomers have more experience and knowledge prompting them to go for better quality foods, more time for planning food shopping and more money for purchasing high quality foods (Worsley, Wang, Hunter, 2010). Gilg and Battershill (1998) found that in the high quality food market, older or retired people had more money and time to search for the tastes they desired (Worsley, Wang, Hunter, 2010).

Generation X cover people born from 1965 through 1980. As of 2014, they are in the age range of 38 to 49 years old. The label long ago overtook the first name affixed to this generation: the Baby Bust (Pew). The Generation X group are building families, and earning more and spending more than any other group (Brewer, 2008). Generation Xers are most price conscious of all generations. Generation X didn't have a great childhood experience and the economy was tough on them when they reached adulthood. These latch-key children grew up quickly, experiencing rising divorce rates and violence (Williams and Page, 2011). They have taken greater responsibility for raising themselves and tend to be less traditional than any other generation (Williams and Page, 2011).

The Millennial generations are children of the original Baby Boomers and their number rivals that of the Baby Boomers (Williams and Page, 2011). The Millennials were born from 1977 to 1994 and as of 2014, their ages are 20 to 37 years. They grew up in a time of immense and fast-paced change including virtually full employment opportunities for women, dual-income households as the standard, a wide array of family types seen as normal, significant respect of ethnic and cultural diversity including a heightened social awareness, and computers in the home and schools (Williams and Page, 2011). Both younger and older millennials are much less loyal to both food brands and traditional grocery stores and much more willing to explore different distribution models 
and spread their shopping across different brands and channels to fulfill their consumable needs (Jefferies, 2012). They are the 'computer connected' generation in every way. They collect and compare information and communicate and shop on-line. They are strapped for money but buy things that are liked rather than those that are the best buy (Brewer, 2008).

\section{Generations' Education and Work}

In the Pew research, millennials are more highly educated when ranked with other generations at comparable ages. More than half of Millennials have at least some college education (54\%), compared with $49 \%$ of Generations Xers, and $36 \%$ of Boomers when they were ages 18 to 28 (PEW, 2010).

Millennials are less likely to be employed (63\%) than Gen Xers (70\%) or Boomers $(66 \%)$ had been at the same age (Pew, 2010). One reason is that overall economic conditions today are less favorable than they were when Gen Xers were ages 18 to 28 in 1995, or when Boomers were that age in 1978 (Pew, 2010). Pew (2010) also stated that Millennials are more likely than earlier generations to be in college, and thus are somewhat more likely to be out of the labor force. 


\section{Generations' Identity}

Figure 2-1: Generation Identity

\begin{tabular}{|c|c|c|c|}
\hline \multicolumn{4}{|c|}{ What Makes Your Generation Unique? } \\
\hline Millennial & Gen $X$ & Boomer & Silent \\
\hline 1. Technology use (24\%) & Technology use (12\%) & Work ethic (17\%) & WW II, Depression (14\%) \\
\hline 2. Music/Pop culture (11\%) & Work ethic $(11 \%)$ & Respectful (14\%) & Smarter $(13 \%)$ \\
\hline 3. Liberal/tolerant (7\%) & Conservative/Trad'l (7\%) & Values/Morals (8\%) & Honest $(12 \%)$ \\
\hline 4. Smarter $(6 \%)$ & Smarter $(6 \%)$ & "Baby Boomers" (6\%) & Work ethic (10\%) \\
\hline 5. Clothes (5\%) & Respectful (5\%) & Smarter $(5 \%)$ & Values/Morals (10\%) \\
\hline
\end{tabular}

Source: Pew Research Center, 2010

According to figure 2-1, the results show that respondents answer about what is unique and distinctive about their generation. Roughly a quarter of those under age 30 (24\%) say technology is what sets their generation apart (Pew, 2010). Other ways in which Millennials see themselves as unique include their music, pop culture and style (11\%), their liberalism and tolerance (7\%) (Pew, 2010). Gen Xers also point to technology as a defining characteristic of their generation- but just $12 \%$ name this as a way in which they differ from other generations. In addition, $11 \%$ of Gen Xers say their work ethic set them apart (Pew, 2010). Baby Boomers also stated that work ethic is a defining characteristic of their generation. Baby Boomers also indicate that respect for others that makes their generation unique (Pew, 2010).

The next step the researcher did is to classify the differences among Generations on values/attitudes, technology use, behaviors/lifestyles, and historical experiences. The results are below in figure 2-2. It shows that Millennials emphasize technology use as the defining characteristic of their generation much more than do their older counterparts (Pew, 2010). In addition, Millennials and Gen Xers are more likely than older generations 
to see factors having to do with behavior and lifestyle as setting their generations apart (Pew, 2010). For the historical experience, Boomers and Silents are more likely to be informed than the younger generations.

Figure 2-2: Differences amongst Generations

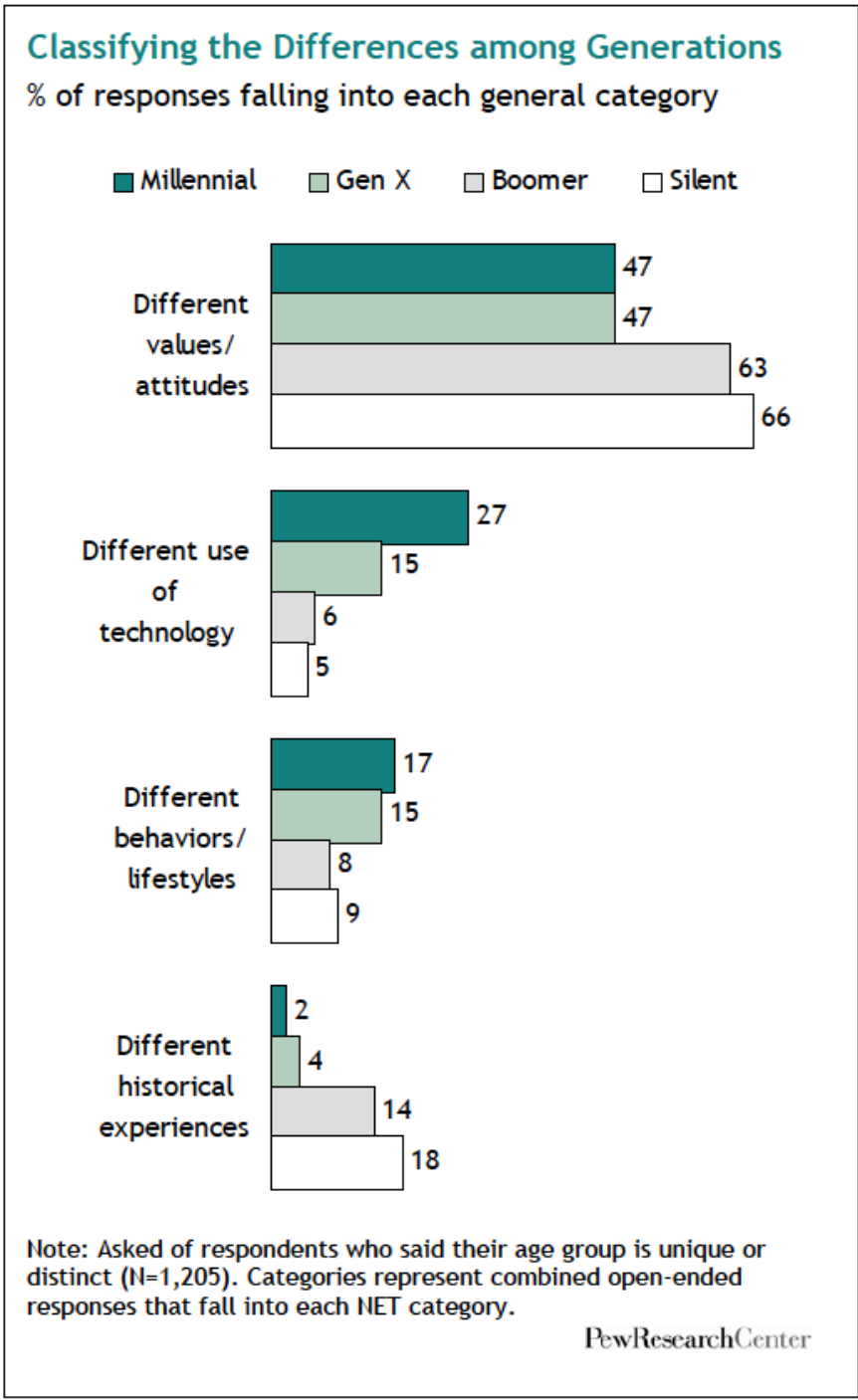

Source: Pew Research Center, 2010

\section{Generational Environmental Behavior}

Environmental awareness has become more important to consumers over the years, but not all the consumers acknowledge how important it is to maintain the 
environment by going green, recycling, and buying green products. From the results shown in the figure 2-3, Millennials lag behind their older counterparts in terms of recycling as roughly seven-in-ten Millennials (69\%) say they recycle paper, plastic or glass at home. That compares with $77 \%$ of Gen Xers, $72 \%$ of Boomers and $77 \%$ of Silents who recycle (Pew, 2010).

Figure 2-3: Generation Environmentally Behavior

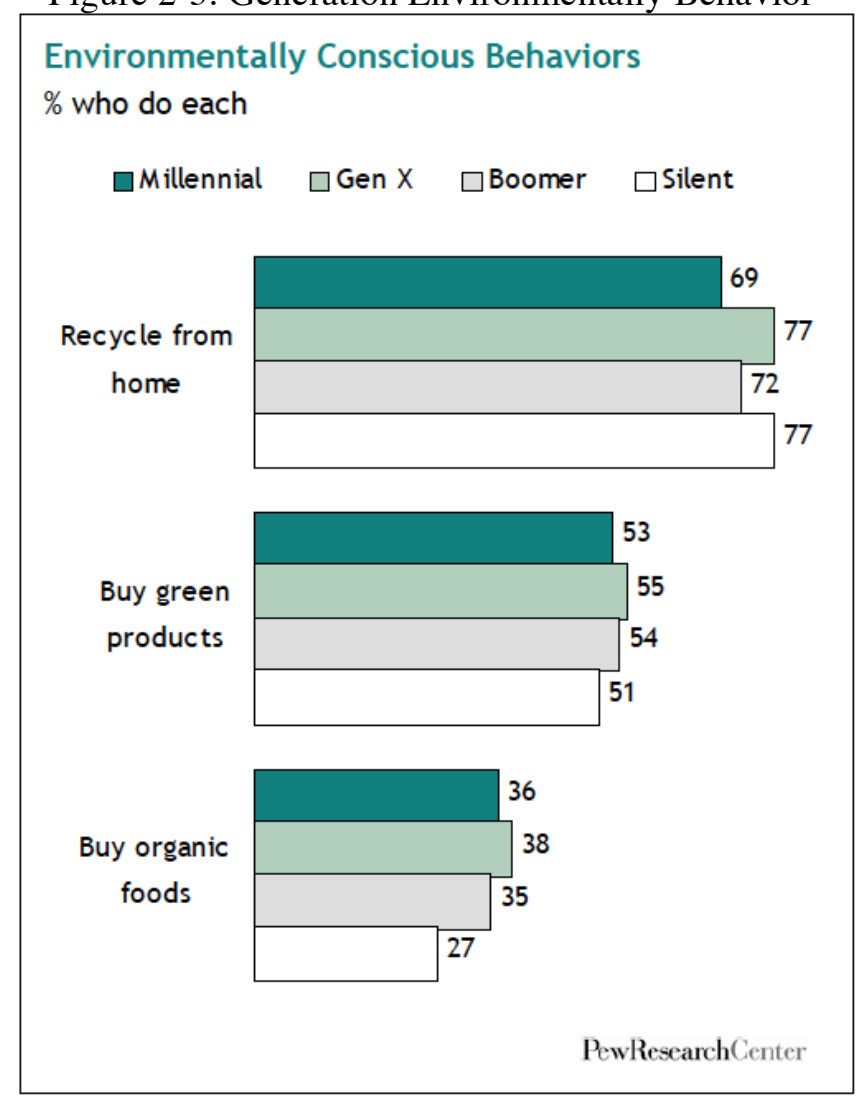

Source: Pew Research Center, 2010

The next section of environmentally conscious behavior is buying green products. All the generations are on the same page to buy green products, even if they are more expensive than non-green products. Across the generations, just over half of Millennials (53\%), Gen Xers (55\%), Boomers (54\%), and Silents (51\%) say they buy green products (Pew, 2010). Buying green products is not as expensive as organic food, as organic food 
is very expensive. This includes nearly equal proportions of Millennials (36\%), Gen Xers (38\%), and Boomers (35\%). The Silents generation are less likely to buy organic foods (27\%) (Pew, 2010).

\section{History of the Meat Consumption}

In the 1970s, the demand for beef continued to increase until between 1976 and 1980, annual per capita beef consumption declined sharply from 94.4 to 76.5 pounds - a decrease of 19 percent (Jolly, 1983). The demand shift changed due to social and health factors that could harm consumer health due to high marbling fat. Increased consumption of poultry in place of beef is an expression of consumers' preference for meat products possessing desirable heath characteristics, such as lower saturated animal fats, and lower cholesterol levels (Moschini and Meilke, 1989). While the changed dynamics of U.S. meat demand are not themselves at issue, identification of factors that cause American consumers to eat less beef now than in the past continues to be a source of controversy among economists (Haley, 2001). The decreased demand for beef changed the supply and demand dynamics, which caused beef prices to increase. Between 1970 and 1980, the index went from 119.5 to 270.3 - up 150.8 points or approximately 126 percent (Fig 2-4), which has adversely affected consumer demand (Jolly, 1983). As years go by, the price for the beef continues to increase and at the same time the demand continues to decrease. Chicken price remains the lowest, which made the demand from consumer to increase. 
Figure 2-4: Beef, Pork, and Chicken price indices.

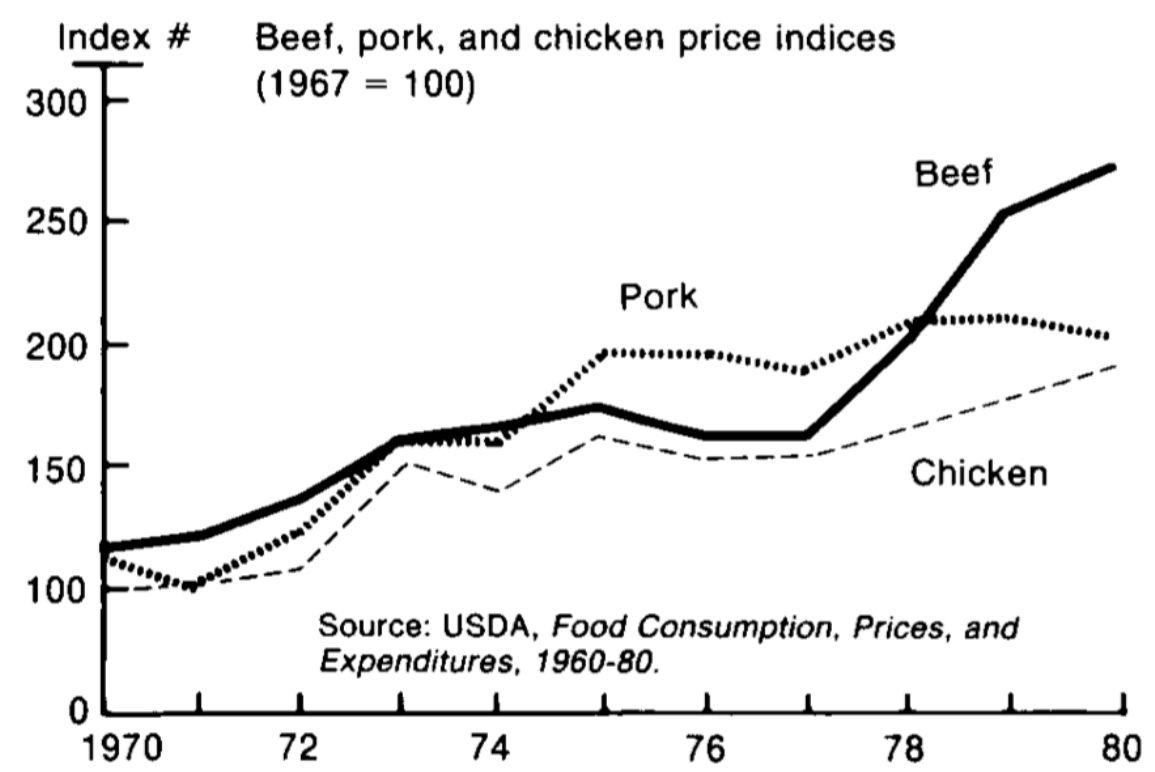

Source: Haley, 2001.

After 1980, U.S. beef consumption continued to decline, while poultry consumption has increased significantly over the past three decades (Haley, 2001). The factors are preference changes, relative prices, and available leisure time for consumer's meat budget for beef, pork, and poultry. Not only these factors, there are health factor concerns that also cause beef demand to decrease. With the lower demand for beef, the USDA (United States Department of Agriculture) and the cattle industry supported to change the USDA grade standards, whose purpose was to better meet perceived consumer demands (Haley, 2001).

Factors changing the demand for meat

The consumer interests and trends continue to change throughout the years. There is steady stream of conferences and lectures on the consumer of the future, on trends in food consumption, about the rapid changes in consumer demand, and about the need for 
innovation of food producers as a way to survive (Grunert, 2006). Product development and innovation are necessary to offset the growth in the availability of food products competing for disposable income (Resurreccion, 2003). It helps ranchers and farmers to operate their industry efficiently but does it help to boost consumer confidence to purchase the product? To develop these types of products effectively, one must evaluate consumer perceptions and understand consumer preferences (Resurreccion, 2003).

Among the most important factors influencing the changes in consumer demand for meat and meat products in the USA are: (1) increased health concerns, (2) change in demographic characteristics, (3) the need for convenience and increased eating away from home, (4) change in distribution, and (5) change in relative prices (USDA/ERS, 2002; Resurreccion, 2003).

Increased health concerns have resulted in a shift away from high-fat, highprotein diets to a trend of more fresh vegetables and fruits in the American diet (Resurreccion, 2003). Veal, beef, and lamb, on the other hand, have experienced significant declines in consumption over the same period (Resurreccion, 2003). It hurt the veal, beef, and lamb industry but now consumers have tools to make their decision. U.S. consumers have used product attributes such as color, leanness, fat content, United States Department of Agriculture (USDA) quality grades, and past experiences to determine beef quality and to make their purchasing decisions (Umberger, McFadden, Smith, 2009).

By understanding the consumers' health concerns, it made the meat industry change their livestock genetics by reducing the fat content of red meat. The meat industry is working steadily to reduce the fat content of red meat achieving significant results (Higgs, 2000). A shift from the very fat breeds like Hereford and Angus to the bigger, 
rangier, less fat, faster growing exotic breeds led to the inconsistent, less tender, less juicy, less succulent products (Higgs, 2000; Resurreccion, 2003). Consumers want less fat but wants consistently flavorful, tender, and juicy beef - characteristics associated with a relatively high degree of marbling (Haley, 2001).

\section{Definition of Organic and Natural}

The consumers' demand for green products continues to increase because they believe that it is good for their health and the environment. The consumer attitude is the same toward eating organic food when it comes to being green friendly. Interest in organic food has grown remarkably as consumers and marketers react to popular media about health and environmental effects of pesticides, genetically modified organisms, and food safety (Hughner, et at all 2007). The definition for organic is that it doesn't use any chemical related to pest control for the crop and no antibodies-resistance and hormone for livestock. Unlike USDA-certified organic products, products designated as "natural" are not subject to an official certification process and bear no standardized label (Onken, en at all, 2011). There is no definition for "natural" in the United States Department of Agriculture because natural has not been standardized within the agriculture industry.

\section{Definition of Locally Grown and Farmer Market}

Locally grown foods (differentiated by the location where foods are grown and raised relative to where they are sold) and farmers markets (differentiated by where and how foods are sold; providing opportunities to sell locally-grown foods but may also sell other foods), can enhance food system sustainability by providing market opportunities 
and price premiums for small and medium sized farms (Conner, et at all, 2010).

Consumers have a demand for food that is locally produced but there is no accepted definition of "local" food under the USDA because it could be county, mile distance, or regions. Though "local" has a geographic connotation, there is no consensus on a definition in terms of the distance between production and consumption (USDA, 2010).

Farmers' markets continue to rise in popularity as consumer demand for obtaining fresh products directly from the farm increases; as a result, farmers' markets have become an increasing visible part in the urban-farm linkage (Wolf, Spittler, Ahern, 2005). 


\title{
CHAPTER 3
}

\author{
Methodology
}

\section{Procedures for Data Collection}

A consumer survey instrument is used to examine consumer behavior and attitudes toward meat purchasing. Dr. Wolf's marketing class and Steven McLennan have collected the data for the research at the supermarkets and farmers' markets throughout San Luis Obispo County from February 2014 to June 2014. There were 290 Respondents to the survey. The questionnaires were used to collect quantitative data to measure the consumer purchasing behavior regarding meat. The objective is to find accurate information from the target market. In order to make that happen, consumers from the supermarket and farmers' market are the right kind of target market to answer the survey especially where they purchased meat from. The target markets for this research are young Millennials, older Millennials, Generation X, and Baby Boomers. The young and older millennials are separate for target markets because there are so many things that changed in their childhood experience.

The questionnaire was created in SurveyMonkey.com. The survey, (see Appendix 1), has 26 questions. It includes eight questions on personal description characteristics, eight questions on general purchasing habits, five questions on the local attribute and defining local, and five questions on meat purchasing habits. 
The first question of the survey asks the respondents if they had or consumed meat products that they had purchased in the last year, which is an elimination question. If the respondents stated that they did eat meat, they finish answering the survey and if the respondents stated that they did not eat meat the survey would be terminated. The second and third questions are related to the Cal Poly brand of wine and food products. The fourth question asked respondents where they have purchased meat products. This question is key as it compares across the generations where they purchase their meat. The next question is about how much money respondents spend in a typical month on meat products, and the sixth question asks how much of one hundred dollars the respondents spend on chicken, beef, pork, and other meat products. Both of these questions show the meat purchasing behaviors and habits. The seventh question asks what percent is ground beef and what percent is steak/roasts that the respondent has served in a month. It's designed to gain better understanding of what kind of meat the respondent likes to eat in a typical month. The eighth question is the most important question in this survey. It has the list of the features for respondents to report are desirable to them when they purchase meat. The results out of this question will provide the answer to meat purchasing attitudes across generations which will help to analyze which features influence their purchasing behaviors. Question 9 to 13 focuses on the how respondent defines local and how important it is it respondents to purchase food products from local producers. It also examines which products it is important for respondents to purchase that are locally produced.

The concept board below (Fig. 3-1) was used for questions 14 to 17 to give a visual for the respondents to evaluate. The concept board was used to showcase the 
product characteristics of local and quality. It also shows the price. Question 15 to asks respondents if the price is too high, too low, or just right.

Figure 3-1: The concept board

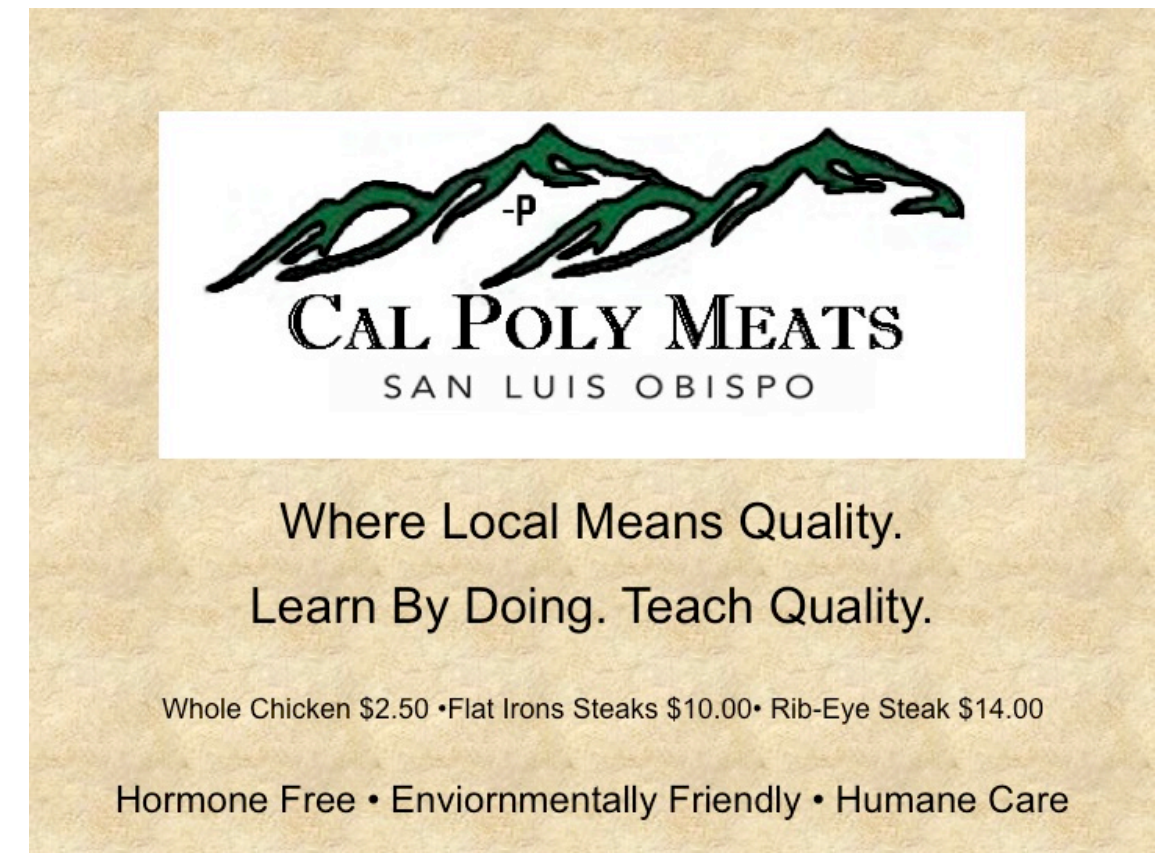

Question 18 asks what kind of media the respondents use to find information about meat. It is useful to learn what kind of media to use to engage the consumer instead of using the wrong kind of media. Questions 19 to 26 are related to personal description characteristics to find out who the target market is and what are their education, lifestyle, and employment.

\section{Procedures for Data Analysis}

Marketing research is a great way to be able to gather, record, and analyze data. Marketing research needs to have a tool to discover the results; Statistical Package for the Social Sciences (SPSS) is an effective tool to use. SPSS is a computer program that is 
able to read data from questionnaire surveys and can produce statistical analyses and reports in a document (Journeys in Survey Research, 2011).

After the data is collected, it was exported from SurveyMonkey.com to both SPSS and Excel. Excel provided tables for analyzing the demographics, media characteristics, and categorical behavior. Statistical testing for differences between generations was done through the SPSS program.

The SPSS program is able to run many different kinds of tests. The four tests most commonly used are frequency, one-way analysis of variance, Chi-square, and independent sample T-Test. Frequency shows the values of a variable and the corresponding numbers and percentages of participants for each value (Voelkl and Gerber, 1999). The one-way analysis of variance (ANOVA) shows the general difference in means between more than two independent groups. It uses the nominal, ordinal, or interval data to be able compare more than two independent groups.

With the post-hoc, it allows researchers to compare the differences in means between individual groups (Wolf, 2009). It includes hypothesis testing, to find the result is to use the P-Value. P-Value is significant in multiple comparisons output. "Significant at the 0.05 level $(\mathrm{P}<0.05)$ " simply means that the probability that a relationship as strong as the observed one can be attributed to sampling error alone is no more than 5 in 100 (Babbie, 2009). When the P-Value is greater than 0.05 then it should accept the hypothesis that there is no difference between two groups. If less than 0.05 , one doesn't accept the hypothesis because there are differences between the two groups.

The Chi-square test is based on the null hypothesis: the assumption that there is no relationship between the two variables in the total population (Babbie, 2009). Chi- 
square is very similar to ANOVA. They both use the P-value to estimate the hypothesis if the groups are the same or different. An independent sample T-Test examines the differences between the means of two independent groups (Wolf, 2009). A T-Test is a tool to know the accurate number between two independent groups related to the question being asking. P-Value is also used for the t-test.

Before using the statistical tests to examine the data in the SPSS, all the questions need to marked as nominal, ordinal, ratio, or interval. This identifies the right statistical tool. The nominal data is data where the number holds a place for a name- for example, age and marital status (Wolf, 2009). Nominal is only used for frequencies and Chi-square testing; frequencies will show the accurate number, and the chi-square shows the p-value for the differences. The ordinal data is the number that is in ranked order like the range of age and income. The test used for the ordinal is the same as the nominal, frequencies and chi-square. The interval data shows each number is an equal distance from the next (Wolf, 2009); it is more of the rating of the product from extremely desirable to not at all desirable. Interval data will be analyzed through t-test and one-way ANOVA to find the differences between two and more than two groups. The ratio data is the data to collect the questions that the respondents fill out blank with numbers, such as dollars spent and number of times they have bought gas in a week. To analyze ratio data is to use a t-test and a one-way ANOVA, the same as interval data. After the testing, there will be a result that will help to create the right kind of marketing by knowing what respondents would like to use and if there are differences between groups. 


\section{Assumption}

After receiving the survey, it is an assumption that the respondents answered the survey honestly. 


\section{CHAPTER 4}

\section{Development of the study}

\section{Target Markets}

We start by analyzing the age composition of the respondents. The first question to review is to find out how many respondents that answered question number 24 , which is lists range of ages, of respondents. The young Millennials' age range is 18 to 27 years with total of 70 respondents. The older Millennials' age range is 28 to 34 years with a total of 72 respondents. The age of 35 to 49 years are Generation Xers with total of 71 respondents. The last group is the Baby Boomers in age of 50 to $65+$ years with total of

\section{2 respondents.}

Table 4-1: Age of Reference Person

\begin{tabular}{|c|c|c|c|c|c|c|}
\hline & Young Millennials & $\begin{array}{c}\text { Older } \\
\text { Millennials }\end{array}$ & $\begin{array}{c}\text { Generation } \\
\text { X }\end{array}$ & $\begin{array}{c}\text { Baby } \\
\text { Boomers }\end{array}$ & Total & $\mathrm{P}$ \\
\hline 18 to 20 & $8.7 \%$ & & & & $2.1 \%$ & $0.000 * *$ \\
\hline 21 to 24 & $42.0 \%$ & & & & $10.0 \%$ & \\
\hline 25 to 27 & $49.3 \%$ & & & & $11.7 \%$ & \\
\hline 28 to 29 & & $36.6 \%$ & & & $9.0 \%$ & \\
\hline 30 to 32 & & $39.4 \%$ & & & $9.7 \%$ & \\
\hline 33 to 34 & & $23.9 \%$ & & & $5.9 \%$ & \\
\hline 35 to 39 & & & $30.0 \%$ & & $7.2 \%$ & \\
\hline 40 to 44 & & & $31.4 \%$ & & $7.6 \%$ & \\
\hline 45 to 49 & & & $38.6 \%$ & & $9.3 \%$ & \\
\hline 50 to 54 & & & & $37.5 \%$ & $10.3 \%$ & \\
\hline 55 to 64 & & & & $43.8 \%$ & $12.1 \%$ & \\
\hline $65+$ years & & & & $18.8 \%$ & $5.2 \%$ & \\
\hline
\end{tabular}

**Significant at the 0.05 level $\quad *$ Significant at the 0.10 level 


\section{Meat Consumption Behavior}

To analyze meat consumption behavior by generation, the survey asked consumers to report which of the following meat products they had purchased for consumption at home in the last year and their meat preferences. The result from table 42 shows that all of the generations have purchased chicken the most with above 95\% occurrence. Beef came in second for all the generations but there are significant differences from baby boomers to all three other generations with $96.3 \%$ preference. Baby boomers are more likely to purchase beef. Generation X and Baby Boomers show a strong percentage with $80 \%$ and $81.4 \%$ for purchasing the pork, which shows a significant difference with 0.008 than young and older millennials with less than 68\%.

The result for the other meat is same as pork but the percentage is lower by $20-30 \%$. Millennials and Generation X consumers purchase less meat than Baby Boomers. This is a concern for the meat industry if they do not increase consumption as they age.

Table 4-2: Which meat products have they purchased for consumption at home in the previous year

\begin{tabular}{|l|c|c|c|c|c|c|}
\hline & $\begin{array}{c}\text { Young } \\
\text { Millennials } \\
(\mathrm{N}=69)\end{array}$ & $\begin{array}{c}\text { Older } \\
\text { Millennials } \\
(\mathrm{N}=71)\end{array}$ & $\begin{array}{c}\text { Generation X } \\
(\mathrm{N}=70)\end{array}$ & $\begin{array}{c}\text { Baby } \\
\text { Boomers } \\
(\mathrm{N}=80)\end{array}$ & Total (N=290) & P-Value \\
\hline Chicken & $97.1 \%$ & $95.8 \%$ & $95.7 \%$ & $97.5 \%$ & $96.6 \%$ & .907 \\
\hline Beef & $78.3 \%$ & $87.3 \%$ & $88.6 \%$ & $96.3 \%$ & $87.9 \%$ & $.010 * *$ \\
\hline Pork & $59.4 \%$ & $67.6 \%$ & $81.4 \%$ & $80.0 \%$ & $72.4 \%$ & $.008 * *$ \\
\hline $\begin{array}{l}\text { Other } \\
\text { Meat }\end{array}$ & $34.8 \%$ & $49.3 \%$ & $51.4 \%$ & $55.0 \%$ & $47.9 \%$ & $.079 *$ \\
\hline
\end{tabular}

$* *$ Significant at the 0.05 level

*Significant at the 0.10 level

\section{Cal Poly Product}

The survey also focused on interest in the Cal Poly Meat. Question 2 any of the respondents had purchased Cal Poly brand food or wine products. In the results, it shows 
all the products show no significant differences across the generations, except for cheese.

Cheese is top Cal Poly product that all generations bought with $34.1 \%$ purchasing percent. The second highest percent is 'I have not purchased any Cal Poly brand food or wine products' with $33.4 \%$.

Table 4-3: Purchased any of the Cal Poly brand food or wine products.

\begin{tabular}{|l|c|c|c|c|c|c|}
\hline & $\begin{array}{c}\text { Young } \\
\text { Millennials } \\
(\mathrm{N}=69)\end{array}$ & $\begin{array}{c}\text { Older } \\
\text { Millennials } \\
(\mathrm{N}=71)\end{array}$ & $\begin{array}{c}\text { Generation } \\
\text { X } \\
(\mathrm{N}=70)\end{array}$ & $\begin{array}{c}\text { Baby } \\
\text { Boomers } \\
(\mathrm{N}=80)\end{array}$ & $\begin{array}{c}\text { Total } \\
(\mathrm{N}=290)\end{array}$ & $\begin{array}{c}\text { P- } \\
\text { Value }\end{array}$ \\
\hline Fruits and/or Vegetables & $23.2 \%$ & $31.0 \%$ & $31.4 \%$ & $23.8 \%$ & $27.2 \%$ & .535 \\
\hline Ice Cream & $21.7 \%$ & $29.6 \%$ & $14.3 \%$ & $16.3 \%$ & $20.3 \%$ & .101 \\
\hline Cheese & $27.5 \%$ & $46.5 \%$ & $28.6 \%$ & $33.8 \%$ & $34.1 \%$ & $.068 *$ \\
\hline Meats & $13.0 \%$ & $18.3 \%$ & $8.6 \%$ & $16.3 \%$ & $14.1 \%$ & .367 \\
\hline Wine & $20.3 \%$ & $22.5 \%$ & $25.7 \%$ & $23.8 \%$ & $23.1 \%$ & .895 \\
\hline $\begin{array}{l}\text { Other Cal Poly Food } \\
\text { Products }\end{array}$ & $29.0 \%$ & $22.5 \%$ & $20.0 \%$ & $30.0 \%$ & $25.5 \%$ & .434 \\
\hline $\begin{array}{l}\text { I have not purchased any Cal } \\
\text { Poly brand food or wine } \\
\text { products. }\end{array}$ & $33.3 \%$ & $29.6 \%$ & $37.1 \%$ & $33.8 \%$ & $33.4 \%$ & .823 \\
\hline
\end{tabular}

**Significant at the 0.05 level

*Significant at the 0.10 level

Question 3 (table 4-4) asked respondents what their perceptions or experiences were with Cal Poly product after they purchased the Cal Poly food brand or wine products. The result shows the four generations agree on the quality, convenience and value of Cal Poly products. The results show the high ratings with $81.3 \%$ for excellent or very good in the quality category. In the convenience to purchase category, the $44.7 \%$ indicated excellent or very good. The value for the money category's highest total percent is $64.4 \%$ indicated excellent or very good. 
Table 4-4: Rate Cal Poly brand food and wine products.

\begin{tabular}{|c|c|c|c|c|c|c|c|}
\hline & & $\begin{array}{c}\text { Young } \\
\text { Millennials } \\
(\mathrm{N}=69)\end{array}$ & $\begin{array}{c}\text { Older } \\
\text { Millennials } \\
(\mathrm{N}=71)\end{array}$ & $\begin{array}{c}\text { Generation } \\
\mathrm{X} \\
(\mathrm{N}=70)\end{array}$ & $\begin{array}{c}\text { Baby } \\
\text { Boomers } \\
(\mathrm{N}=80)\end{array}$ & $\begin{array}{c}\text { Total } \\
(\mathrm{N}=290)\end{array}$ & $\begin{array}{c}\text { P- } \\
\text { Value }\end{array}$ \\
\hline \multirow[t]{5}{*}{ Quality } & Poor & & & $1.4 \%$ & & $.3 \%$ & 0.102 \\
\hline & $\begin{array}{c}\text { Not Very } \\
\text { Good }\end{array}$ & $1.5 \%$ & & & $1.3 \%$ & $.7 \%$ & \\
\hline & $\begin{array}{c}\text { Somewhat } \\
\text { Good }\end{array}$ & $19.1 \%$ & $16.9 \%$ & $18.8 \%$ & $12.5 \%$ & $16.7 \%$ & \\
\hline & Very Good & $51.5 \%$ & $53.5 \%$ & $56.5 \%$ & $37.5 \%$ & $49.3 \%$ & \\
\hline & Excellent & $27.9 \%$ & $29.6 \%$ & $23.2 \%$ & $48.8 \%$ & $33.0 \%$ & \\
\hline \multirow{5}{*}{$\begin{array}{l}\text { Convenience } \\
\text { to purchase }\end{array}$} & Poor & $7.4 \%$ & $4.2 \%$ & $5.8 \%$ & $6.4 \%$ & $5.9 \%$ & 0.666 \\
\hline & $\begin{array}{c}\text { Not Very } \\
\text { Good }\end{array}$ & $19.1 \%$ & $25.4 \%$ & $21.7 \%$ & $15.4 \%$ & $20.3 \%$ & \\
\hline & $\begin{array}{c}\text { Somewhat } \\
\text { Good }\end{array}$ & $26.5 \%$ & $32.4 \%$ & $29.0 \%$ & $28.2 \%$ & $29.0 \%$ & \\
\hline & Very Good & $32.4 \%$ & $25.4 \%$ & $27.5 \%$ & $23.1 \%$ & $26.9 \%$ & \\
\hline & Excellent & $14.7 \%$ & $12.7 \%$ & $15.9 \%$ & $26.9 \%$ & $17.8 \%$ & \\
\hline \multirow[t]{5}{*}{$\begin{array}{l}\text { Value for } \\
\text { the money }\end{array}$} & Poor & & & & & & \\
\hline & $\begin{array}{c}\text { Not Very } \\
\text { Good }\end{array}$ & $2.9 \%$ & $5.6 \%$ & $5.7 \%$ & $5.2 \%$ & $4.9 \%$ & 0.354 \\
\hline & $\begin{array}{c}\text { Somewhat } \\
\text { Good }\end{array}$ & $33.8 \%$ & $38.0 \%$ & $21.4 \%$ & $29.9 \%$ & $30.8 \%$ & \\
\hline & Very Good & $50.0 \%$ & $35.2 \%$ & $50.0 \%$ & $39.0 \%$ & $43.4 \%$ & \\
\hline & Excellent & $13.2 \%$ & $21.1 \%$ & $22.9 \%$ & $26.0 \%$ & $21.0 \%$ & \\
\hline
\end{tabular}

**Significant at the 0.05 level

*Significant at the 0.10 level

Question 4 results shows that shoppers from all generations shop in similar locations. Chain grocery stores are their favored place to purchase meat with over $83.1 \%$ purchasing there (table 4-5). Costco is the second favorable with 57.2\%, which is much lower than the chain grocery store, but chain grocery stores have multiple grocery stores such as Albertsons, Ralphs, Vons, etc. Costco is one of the biggest stores that carry high quality meats. Fresh \& Easy, is a more likely choice for Millennials, which differed from generation $\mathrm{X}$ and baby boomers by $10 \%$. 
Table 4-5: Where have you purchased your meat products?

\begin{tabular}{|l|c|c|c|c|c|c|}
\hline & $\begin{array}{c}\text { Young } \\
\text { Millennials } \\
(\mathrm{N}=69)\end{array}$ & $\begin{array}{c}\text { Older } \\
\text { Millennials } \\
(\mathrm{N}=71)\end{array}$ & $\begin{array}{c}\text { Generation } \\
\mathrm{X} \\
(\mathrm{N}=70)\end{array}$ & $\begin{array}{c}\text { Baby } \\
\text { Boomers } \\
(\mathrm{N}=80)\end{array}$ & $\begin{array}{c}\text { Total } \\
(\mathrm{N}=290)\end{array}$ & $\begin{array}{c}\text { P- } \\
\text { Value }\end{array}$ \\
\hline $\begin{array}{l}\text { Chain grocery store } \\
\text { (Albertsons, Ralphs, Vons) }\end{array}$ & $82.6 \%$ & $80.3 \%$ & $87.1 \%$ & $82.5 \%$ & $83.1 \%$ & 0.741 \\
\hline Trader Joe's & $52.2 \%$ & $53.5 \%$ & $55.7 \%$ & $55.0 \%$ & $54.1 \%$ & 0.976 \\
\hline Costco & $59.4 \%$ & $56.3 \%$ & $51.4 \%$ & $61.3 \%$ & $57.2 \%$ & 0.648 \\
\hline New Frontiers & $24.6 \%$ & $31.0 \%$ & $24.3 \%$ & $30.0 \%$ & $27.6 \%$ & 0.723 \\
\hline Spencer's & $8.7 \%$ & $12.7 \%$ & $17.1 \%$ & $17.5 \%$ & $14.1 \%$ & 0.380 \\
\hline Farmer's Market & $23.2 \%$ & $26.8 \%$ & $22.9 \%$ & $13.8 \%$ & $21.4 \%$ & 0.239 \\
\hline Fresh \& Easy & $13.0 \%$ & $14.1 \%$ & $5.7 \%$ & $3.8 \%$ & $9.0 \%$ & 0.064 \\
\hline Restaurant & $31.9 \%$ & $39.4 \%$ & $32.9 \%$ & $33.8 \%$ & $34.5 \%$ & 0.782 \\
\hline $\begin{array}{l}\text { Cal Poly's Meat Processing } \\
\text { Center }\end{array}$ & $7.2 \%$ & $5.6 \%$ & $7.1 \%$ & $13.8 \%$ & $8.6 \%$ & 0.280 \\
\hline
\end{tabular}

$* *$ Significant at the 0.05 level

*Significant at the 0.10 level

Question 5 shows how much respondents spend in a typical month on meat. The results show no significant difference on how much all four generations spend on their meat. Chicken shows the highest purchasing dollars with a total average of $\$ 48.45$. Beef came second with $\$ 35.77$, and pork in fourth with $\$ 19.05$. According to table $1-2$ which is national data, the result shows that the beef is high preferable to purchase for the older consumers in national than locally.

Table 4-6: How much money do you spend in a typical month on meat products

\begin{tabular}{|l|c|c|c|c|c|c|}
\hline & $\begin{array}{c}\text { Young } \\
\text { Millennials } \\
(\mathrm{N}=57)\end{array}$ & $\begin{array}{c}\text { Older } \\
\text { Millennials } \\
(\mathrm{N}=61)\end{array}$ & $\begin{array}{c}\text { Generation } \\
\mathrm{X} \\
(\mathrm{N}=64)\end{array}$ & $\begin{array}{c}\text { Baby } \\
\text { Boomers } \\
(\mathrm{N}=74)\end{array}$ & $\begin{array}{c}\text { Total } \\
(\mathrm{N}=256)\end{array}$ & P-Value \\
\hline Chicken & $\$ 50.18$ & $\$ 47.70$ & $\$ 50.87$ & $\$ 45.54$ & $\$ 48.45$ & 0.589 \\
\hline Beef & $\$ 32.10$ & $\$ 33.58$ & $\$ 38.94$ & $\$ 37.93$ & $\$ 35.77$ & 0.276 \\
\hline Pork & $\$ 20.20$ & $\$ 17.51$ & $\$ 20.50$ & $\$ 18.19$ & $\$ 19.05$ & 0.638 \\
\hline Other & $\$ 17.18$ & $\$ 25.36$ & $\$ 22.59$ & $\$ 21.03$ & $\$ 21.73$ & 0.472 \\
\hline
\end{tabular}

**Significant at the 0.05 level *Significant at the 0.10 level 
Table 4-7 shows the total amount of dollars spent on all of the meats and it shows there is significant difference. Baby boomers spent the most in a typical month than all other generations with $\$ 134.78$. The generations Xers come in second with $\$ 113.95$.

Table 4-7: How much money do you spend in a typical month on total meat products

\begin{tabular}{|l|c|c|c|c|c|c|}
\hline & $\begin{array}{c}\text { Young } \\
\text { Millennials } \\
(\mathrm{N}=57)\end{array}$ & $\begin{array}{c}\text { Older } \\
\text { Millennials } \\
(\mathrm{N}=61)\end{array}$ & $\begin{array}{c}\text { Generation X } \\
(\mathrm{N}=64)\end{array}$ & $\begin{array}{c}\text { Baby } \\
\text { Boomers } \\
(\mathrm{N}=74)\end{array}$ & $\begin{array}{c}\text { Total } \\
(\mathrm{N}=256)\end{array}$ & $\begin{array}{c}\mathrm{P}- \\
\text { Value }\end{array}$ \\
\hline Total & $\$ 90.00$ & $\$ 92.84$ & $\$ 113.95$ & $\$ 134.78$ & $\$ 109.61$ & $.003 * *$ \\
\hline
\end{tabular}

**Significant at the 0.05 level *Significant at the 0.10 level

The results for question 7 show the difference between ground beef and steaks/roasts to determine which generation uses which cut the most in a month. It shows that there is no significant difference across all of the four generations. According to table 4-7 and 4-8, the results show that there is little difference between young millennials and the other three generations. The young millennials serve ground beef three percent more than steaks/roasts. The older millennials, generation Xers, and baby boomers serve the steaks/roasts more than the ground beef in a month.

Table 4-8: Of the number of times that you serve beef in a month, what percent is ground beef?

\begin{tabular}{|l|c|c|c|c|c|c|}
\hline & $\begin{array}{c}\text { Young } \\
\text { Millennials } \\
(\mathrm{N}=63)\end{array}$ & $\begin{array}{c}\text { Older } \\
\text { Millennials } \\
(\mathrm{N}=60)\end{array}$ & $\begin{array}{c}\text { Generation X } \\
(\mathrm{N}=59)\end{array}$ & $\begin{array}{c}\text { Baby } \\
\text { Boomers } \\
(\mathrm{N}=72)\end{array}$ & $\begin{array}{c}\text { Total } \\
(\mathrm{N}=254)\end{array}$ & P-Value \\
\hline Ground beef & 50.08 & 42.90 & 39.07 & 41.74 & 43.46 & 0.153 \\
\hline
\end{tabular}

$* *$ Significant at the 0.05 level $\quad *$ Significant at the 0.10 level 
Table 4-9: Of the number of times that you serve beef in a month, what percent is steak/roasts?

\begin{tabular}{|l|c|c|c|c|c|c|}
\hline & $\begin{array}{c}\text { Young } \\
\text { Millennials } \\
(\mathrm{N}=59)\end{array}$ & $\begin{array}{c}\text { Older } \\
\text { Millennials } \\
(\mathrm{N}=58)\end{array}$ & $\begin{array}{c}\text { Generation X } \\
(\mathrm{N}=58)\end{array}$ & $\begin{array}{c}\text { Baby } \\
\text { Boomers } \\
(\mathrm{N}=75)\end{array}$ & $\begin{array}{c}\text { Total } \\
(\mathrm{N}=250)\end{array}$ & P-Value \\
\hline Steaks/Roasts & 47.71 & 53.26 & 56.98 & 55.67 & 53.54 & 0.277 \\
\hline
\end{tabular}

$* *$ Significant at the 0.05 level $\quad *$ Significant at the 0.10 level

Question 8 focuses on which features are the most desirable when it comes to purchasing the meat. The resulting scale, where extremely desirable is a score of 5, very desirable $=4$, somewhat desirable $=3$, slightly desirable $=2$, not at all desirable $=1$ shows the mean of the result (table 4-9). The highest desirability that for respondents' decisions to purchase the meat is good value for the money and second is no hormones added. The organic product is rated the least desirability for young millennial, generation $\mathrm{X}$ and baby boomers.

The result shows that there is no significant difference except for two. The first feature with a difference is not fed animal by-product. The results show that young millennials show the lowest desirability with 3.49 and the generation Xers shows the highest desirable with 4.01. Using a post hoc test for the one-Way ANOVA, young millennials rate not fed animal byproducts lower than generation Xers and Baby Boomers. Perhaps they were too young to be aware of the mad cow disease problems from animal by-products. The second feature that shows a significant difference with 0.066 is for the local brand. The older millennials show the rate for the local brand lowest desirability with 3.33 , which is lowest out of all the features rated by them. Using a post hoc test for the one-Way ANOVA, older millennials rate local lower than generation Xers and Baby Boomers. 
Table 4-10: Rate the desirability of each feature to you when you purchase meat.

\begin{tabular}{|l|c|c|c|c|c|c|}
\hline & $\begin{array}{c}\text { Young } \\
\text { Millennials } \\
(\mathrm{N}=69)\end{array}$ & $\begin{array}{c}\text { Older } \\
\text { Millennials } \\
(\mathrm{N}=71)\end{array}$ & $\begin{array}{c}\text { Generation } \\
\mathrm{X} \\
(\mathrm{N}=70)\end{array}$ & $\begin{array}{c}\text { Baby } \\
\text { Boomers } \\
(\mathrm{N}=80)\end{array}$ & $\begin{array}{c}\text { Total } \\
(\mathrm{N}=290)\end{array}$ & $\begin{array}{c}\text { P- } \\
\text { Value }\end{array}$ \\
\hline Good value for the money & 4.37 & 4.21 & 4.30 & 4.37 & 4.31 & 0.532 \\
\hline No hormones added & 3.89 & 3.93 & 3.97 & 4.08 & 3.97 & 0.723 \\
\hline Not treated with antibodies & 3.65 & 3.76 & 3.90 & 3.92 & 3.81 & 0.400 \\
\hline Not fed animal by-products & 3.49 & 3.74 & 4.01 & 3.96 & 3.81 & $0.028^{* *}$ \\
\hline Natural & 3.69 & 3.55 & 3.79 & 3.73 & 3.69 & 0.621 \\
\hline Local brand & 3.57 & 3.33 & 3.74 & 3.73 & 3.60 & $0.066^{*}$ \\
\hline Organic & 3.16 & 3.46 & 3.41 & 3.53 & 3.40 & 0.235 \\
\hline
\end{tabular}

$* *$ Significant at the 0.05 level

*Significant at the 0.10 level

\section{Define Local}

There is no significant difference in question 9 across the generations when it comes to being involved in local food initiatives. The majority of the generations are not involved.

Table 4-11: Currently involved in local food initiatives.

\begin{tabular}{|l|c|c|c|c|c|c|}
\hline & $\begin{array}{c}\text { Young } \\
\text { Millennials } \\
(\mathrm{N}=69)\end{array}$ & $\begin{array}{c}\text { Older } \\
\text { Millennials } \\
(\mathrm{N}=71)\end{array}$ & $\begin{array}{c}\text { Generation X } \\
(\mathrm{N}=70)\end{array}$ & $\begin{array}{c}\text { Baby } \\
\text { Boomers } \\
(\mathrm{N}=80)\end{array}$ & $\begin{array}{c}\text { Total } \\
(\mathrm{N}=290)\end{array}$ & P-Value \\
\hline Yes & $19.1 \%$ & $32.9 \%$ & $21.7 \%$ & $30.0 \%$ & $26.1 \%$ & 0.197 \\
\hline No & $80.9 \%$ & $67.1 \%$ & $78.3 \%$ & $70.0 \%$ & $73.9 \%$ & \\
\hline
\end{tabular}

$* *$ Significant at the 0.05 level $\quad *$ Significant at the 0.10 level

According to table 4-10, the local brand is not the most desirable for generations to purchase the meat and few are involved in local initiatives. This research asks consumers what "local" means to them regarding food. Most consumers, 74\%, believe local is less than 50 miles. The results for what their meaning for local shows no significant difference across the generations. 
Table 4-12: Define Local.

\begin{tabular}{|l|c|c|c|c|c|c|}
\hline & $\begin{array}{c}\text { Young } \\
\text { Millennials } \\
(\mathrm{N}=69)\end{array}$ & $\begin{array}{c}\text { Older } \\
\text { Millennials } \\
(\mathrm{N}=71)\end{array}$ & $\begin{array}{c}\text { Generation X } \\
(\mathrm{N}=70)\end{array}$ & $\begin{array}{c}\text { Baby } \\
\text { Boomers } \\
(\mathrm{N}=80)\end{array}$ & $\begin{array}{c}\text { Total } \\
(\mathrm{N}=290)\end{array}$ & P-Value \\
\hline$<10$ Miles & $11.6 \%$ & $8.6 \%$ & $8.6 \%$ & $9.0 \%$ & $9.4 \%$ & 0.384 \\
\hline$<30$ Miles & $36.2 \%$ & $34.3 \%$ & $32.9 \%$ & $35.9 \%$ & $34.8 \%$ & \\
\hline$<50$ Miles & $27.5 \%$ & $30.0 \%$ & $22.9 \%$ & $35.9 \%$ & $29.3 \%$ & \\
\hline$<100$ Miles & $13.0 \%$ & $18.6 \%$ & $31.4 \%$ & $12.8 \%$ & $18.8 \%$ & \\
\hline $100+$ Miles & $4.3 \%$ & $1.4 \%$ & $2.9 \%$ & $2.6 \%$ & $2.8 \%$ & \\
\hline $\begin{array}{l}\text { I Don't } \\
\text { Know }\end{array}$ & $7.2 \%$ & $7.1 \%$ & $1.4 \%$ & $3.8 \%$ & $4.9 \%$ & \\
\hline
\end{tabular}

**Significant at the 0.05 level

*Significant at the 0.10 level

The next part of examining the meaning of "local" defines local as a municipal entity. There is no significant difference across four generations. In the results, the majority of the generations chose "your county" as local.

Table 4-13: Define local to be from.

\begin{tabular}{|l|c|c|c|c|c|c|}
\hline & $\begin{array}{c}\text { Young } \\
\text { Millennials } \\
(\mathrm{N}=69)\end{array}$ & $\begin{array}{c}\text { Older } \\
\text { Millennials } \\
(\mathrm{N}=71)\end{array}$ & $\begin{array}{c}\text { Generation X } \\
(\mathrm{N}=70)\end{array}$ & $\begin{array}{c}\text { Baby } \\
\text { Boomers } \\
(\mathrm{N}=80)\end{array}$ & $\begin{array}{c}\text { Total } \\
(\mathrm{N}=290)\end{array}$ & P-Value \\
\hline $\begin{array}{l}\text { Your home } \\
\text { town/city }\end{array}$ & $19.1 \%$ & $21.1 \%$ & $25.7 \%$ & $13.8 \%$ & $19.7 \%$ & 0.827 \\
\hline Your County & $57.4 \%$ & $60.6 \%$ & $54.3 \%$ & $70.0 \%$ & $60.9 \%$ & \\
\hline Your State & $17.6 \%$ & $11.3 \%$ & $14.3 \%$ & $10.0 \%$ & $13.1 \%$ & \\
\hline Western States & $1.5 \%$ & $2.8 \%$ & $1.4 \%$ & $3.8 \%$ & $2.4 \%$ & \\
\hline US & $4.4 \%$ & $2.8 \%$ & $2.9 \%$ & $1.3 \%$ & $2.8 \%$ & \\
\hline I Don't Know & & $1.4 \%$ & $1.4 \%$ & $1.3 \%$ & $1.0 \%$ & \\
\hline
\end{tabular}

**Significant at the 0.05 level

*Significant at the 0.10 level

Local was examined again comparing mileage and locality. Locality, such as city, county and state was chosen over mileage by $69.1 \%$ of respondents. There is no significant difference of the definition based on generation. Respondents were asked which one means more to them when deciding what local is. Both young and older 
millennials have the same result as their response to locality is higher than both generation $\mathrm{x}$ and baby boomers.

Table 4-14: Which mileage or locality mean what local is

\begin{tabular}{|l|c|c|c|c|c|c|}
\hline & $\begin{array}{c}\text { Young } \\
\text { Millennials } \\
(\mathrm{N}=69)\end{array}$ & $\begin{array}{c}\text { Older } \\
\text { Millennials } \\
(\mathrm{N}=71)\end{array}$ & $\begin{array}{c}\text { Generation X } \\
(\mathrm{N}=70)\end{array}$ & $\begin{array}{c}\text { Baby } \\
\text { Boomers } \\
(\mathrm{N}=80)\end{array}$ & $\begin{array}{c}\text { Total } \\
(\mathrm{N}=290)\end{array}$ & $\begin{array}{c}\text { P- } \\
\text { Value }\end{array}$ \\
\hline $\begin{array}{l}\text { Mileage (Set distance } \\
\text { away) }\end{array}$ & $27.5 \%$ & $26.1 \%$ & $34.8 \%$ & $34.6 \%$ & $30.9 \%$ & 0.551 \\
\hline $\begin{array}{l}\text { Locality (City, County, or } \\
\text { State) }\end{array}$ & $72.5 \%$ & $73.9 \%$ & $65.2 \%$ & $65.4 \%$ & $69.1 \%$ & \\
\hline
\end{tabular}

**Significant at the 0.05 level

*Significant at the 0.10 level

Question 13 asked how important is it for respondents to purchase local fruits, local vegetables, local meats, or local wines. The scale used was: extremely important is a score of 5 , very important $=4$, somewhat important $=3$, slightly important $=2$, not at all important $=1$. There are significant difference in local fruits, vegetables, and wines . There is no significant difference in local meats. The baby boomers indicate higher importance for local fruits, vegetables, and wines than among the three generations. The young millennials show the least importance toward local wine.

Table 4-15: How important is it to you to purchase?

\begin{tabular}{|l|c|c|c|c|c|c|}
\hline & $\begin{array}{c}\text { Young } \\
\text { Millennials } \\
(\mathrm{N}=68)\end{array}$ & $\begin{array}{c}\text { Older } \\
\text { Millennials } \\
(\mathrm{N}=71)\end{array}$ & $\begin{array}{c}\text { Generation X } \\
(\mathrm{N}=70)\end{array}$ & $\begin{array}{c}\text { Baby } \\
\text { Boomers } \\
(\mathrm{N}=79)\end{array}$ & $\begin{array}{c}\text { Total } \\
(\mathrm{N}=288)\end{array}$ & P-Value \\
\hline Local fruits & 3.62 & 3.68 & 3.76 & 4.04 & 3.78 & $.051 *$ \\
\hline $\begin{array}{l}\text { Local } \\
\text { vegetables }\end{array}$ & 3.61 & 3.73 & 3.81 & 4.05 & 3.81 & $.042 * *$ \\
\hline Local meats & 3.29 & 3.34 & 3.51 & 3.63 & 3.45 & .126 \\
\hline Local wines & 2.69 & 3.35 & 3.00 & 3.48 & 3.14 & $.000 * *$ \\
\hline
\end{tabular}

**Significant at the 0.05 level

*Significant at the 0.10 level 


\section{Attitudes toward Cal Poly Meat}

The concept board to showcase the Cal Poly Meat Processing Center was showed to respondents via a visual aid to help them answer the questions about purchasing it (Fig 4-1).

Figure 4-1: The concept board

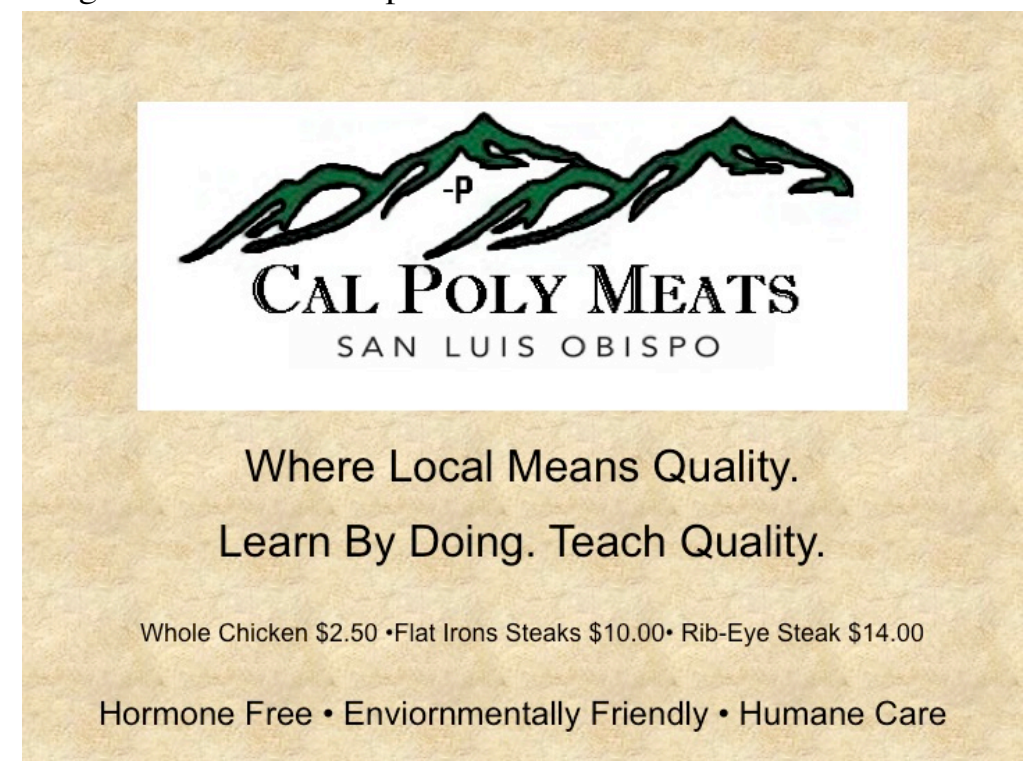

Almost two-thirds, $64.2 \%$ of the respondents indicated they were $70 \%$ or more likely to purchase Cal Poly meat. There was not difference in the appeal of the Cal Poly meat by generation. 
Table 4-16: How likely would you be purchase them in the next year

\begin{tabular}{|c|c|c|c|c|c|c|}
\hline & $\begin{array}{c}\text { Young } \\
\text { Millennials } \\
(\mathrm{N}=68)\end{array}$ & $\begin{array}{c}\text { Older } \\
\text { Millennials } \\
(\mathrm{N}=71)\end{array}$ & $\begin{array}{l}\text { Generation } \mathrm{X} \\
\quad(\mathrm{N}=70)\end{array}$ & $\begin{array}{c}\text { Baby } \\
\text { Boomers } \\
(\mathrm{N}=79)\end{array}$ & $\begin{array}{c}\text { Total } \\
(\mathrm{N}=288)\end{array}$ & $\begin{array}{c}\mathrm{P}- \\
\text { Value }\end{array}$ \\
\hline $\begin{array}{l}\text { Certain Will Buy (99 } \\
\text { chances in 100) }\end{array}$ & $8.8 \%$ & $8.6 \%$ & $15.7 \%$ & $21.3 \%$ & $13.9 \%$ & 0.388 \\
\hline $\begin{array}{l}\text { Almost Sure Will Buy } \\
(90 \text { chances in } 100)\end{array}$ & $10.3 \%$ & $20.0 \%$ & $20.0 \%$ & $20.0 \%$ & $17.7 \%$ & \\
\hline $\begin{array}{l}\text { Very Probable Will Buy } \\
(80 \text { chances in } 100)\end{array}$ & $25.0 \%$ & $15.7 \%$ & $17.1 \%$ & $18.8 \%$ & $19.1 \%$ & \\
\hline $\begin{array}{l}\text { Probably Will Buy (70 } \\
\text { chances in 100) }\end{array}$ & $16.2 \%$ & $17.1 \%$ & $11.4 \%$ & $10.0 \%$ & $13.5 \%$ & \\
\hline $\begin{array}{l}\text { Good Possibility (60 } \\
\text { chances in 100) }\end{array}$ & $7.4 \%$ & $14.3 \%$ & $8.6 \%$ & $11.3 \%$ & $10.4 \%$ & \\
\hline $\begin{array}{l}\text { Fairly Good Possibility } \\
(50 \text { chances in } 100)\end{array}$ & $10.3 \%$ & $8.6 \%$ & $11.4 \%$ & $6.3 \%$ & $9.0 \%$ & \\
\hline $\begin{array}{l}\text { Fair Possibility Will Buy } \\
\text { (40 chances in } 100)\end{array}$ & $4.4 \%$ & $10.0 \%$ & $2.9 \%$ & $3.8 \%$ & $5.2 \%$ & \\
\hline $\begin{array}{l}\text { Some Possibility ( } 30 \\
\text { chances in 100) }\end{array}$ & $5.9 \%$ & $2.9 \%$ & $7.1 \%$ & $6.3 \%$ & $5.6 \%$ & \\
\hline $\begin{array}{l}\text { Slight possibility }(20 \\
\text { chances in 100) }\end{array}$ & $5.9 \%$ & & $2.9 \%$ & $1.3 \%$ & $2.4 \%$ & \\
\hline $\begin{array}{l}\text { Very Slight Possibility } \\
(10 \text { chances in } 100)\end{array}$ & $4.4 \%$ & $2.9 \%$ & $1.4 \%$ & & $2.1 \%$ & \\
\hline $\begin{array}{l}\text { No Chance You Will Buy } \\
(0 \text { chances in } 100)\end{array}$ & $1.5 \%$ & & $1.4 \%$ & $1.3 \%$ & $1.0 \%$ & \\
\hline
\end{tabular}

**Significant at the 0.05 level

*Significant at the 0.10 level

The concept board was also used for question 15 to question the price points to the respondents. The price of the Cal Poly branded meat products shows no significant difference across the respondents by generation, as seen in (Table 4-17). Sixty percent of the respondents indicated the price was just right. This is similar to the percent that indicated they are $70 \%$ or more likely to buy Cal Poly meat.

Table 4-17: Is the price of Cal Poly Meat products?

\begin{tabular}{|l|c|c|c|c|c|c|}
\hline & $\begin{array}{c}\text { Young } \\
\text { Millennials } \\
(\mathrm{N}=68)\end{array}$ & $\begin{array}{c}\text { Older } \\
\text { Millennials } \\
(\mathrm{N}=71)\end{array}$ & $\begin{array}{c}\text { Generation } \\
\mathrm{X} \\
(\mathrm{N}=70)\end{array}$ & $\begin{array}{c}\text { Baby } \\
\text { Boomers } \\
(\mathrm{N}=79)\end{array}$ & $\begin{array}{c}\text { Total } \\
(\mathrm{N}=288)\end{array}$ & P-Value \\
\hline Too high & $38.2 \%$ & $42.9 \%$ & $25.7 \%$ & $38.8 \%$ & $36.5 \%$ & 0.356 \\
\hline Too low & $1.5 \%$ & $2.9 \%$ & $5.7 \%$ & $2.5 \%$ & $3.1 \%$ & \\
\hline Just right & $60.3 \%$ & $54.3 \%$ & $68.6 \%$ & $58.8 \%$ & $60.4 \%$ & \\
\hline
\end{tabular}

**Significant at the 0.05 level

*Significant at the 0.10 level 
Table 4.5 shows $21 \%$ of the consumers have purchased meat at a farmers' market and there was no difference by generation. Question 16 shows no significant difference in interest by generation. The result shows that all of the generations are on the same page with $36.3 \%$ extremely of very likely to buy at a local farmers' market.

Table 4-18: How likely are you to purchase a Cal Poly meat product at a local farmers' market

\begin{tabular}{|l|c|c|c|c|c|c|}
\hline & $\begin{array}{c}\text { Young } \\
\text { Millennials } \\
(\mathrm{N}=68)\end{array}$ & $\begin{array}{c}\text { Older } \\
\text { Millennials } \\
(\mathrm{N}=71)\end{array}$ & $\begin{array}{c}\text { Generation X } \\
(\mathrm{N}=70)\end{array}$ & $\begin{array}{c}\text { Baby Boomers } \\
(\mathrm{N}=79)\end{array}$ & $\begin{array}{c}\text { Total } \\
(\mathrm{N}=288)\end{array}$ & $\begin{array}{c}\text { P- } \\
\text { Value }\end{array}$ \\
\hline Extremely likely & & $7.1 \%$ & $4.3 \%$ & $8.8 \%$ & $5.2 \%$ & 0.198 \\
\hline Very likely & $27.3 \%$ & $32.9 \%$ & $34.3 \%$ & $30.0 \%$ & $31.1 \%$ & \\
\hline Somewhat likely & $37.9 \%$ & $30.0 \%$ & $41.4 \%$ & $27.5 \%$ & $33.9 \%$ & \\
\hline Not very likely & $24.2 \%$ & $25.7 \%$ & $14.3 \%$ & $21.3 \%$ & $21.3 \%$ & \\
\hline Not at all likely & $10.6 \%$ & $4.3 \%$ & $5.7 \%$ & $12.5 \%$ & $8.4 \%$ & \\
\hline
\end{tabular}

**Significant at the 0.05 level

*Significant at the 0.10 level

The Cal Poly Meat Processing Center sells the meat at the Cal Poly campus location. There is not free parking and it's required for consumers to pay the parking meter in order to park their car there. It's potential that people are more likely to go to the Cal Poly campus to purchase Cal Poly meat if there was free parking available. The generations have similar likelihood to go to Cal Poly Campus to purchase meat (table 419). The extremely of very likely purchasers are $27.9 \%$ of respondents and the not very or not at all likely are $40.1 \%$. 
Table 4-19: How likely are you to go to the Cal Poly campus to purchase Cal Poly meats, if there was free parking available

\begin{tabular}{|c|c|c|c|c|c|c|}
\hline & $\begin{array}{c}\text { Young } \\
\text { Millennials } \\
(\mathrm{N}=68)\end{array}$ & $\begin{array}{c}\text { Older } \\
\text { Millennials } \\
(\mathrm{N}=71)\end{array}$ & $\begin{array}{c}\text { Generation } \\
\mathrm{X} \quad(\mathrm{N}=70)\end{array}$ & $\begin{array}{c}\text { Baby } \\
\text { Boomers } \\
(\mathrm{N}=79)\end{array}$ & $\begin{array}{c}\text { Total } \\
(\mathrm{N}=288)\end{array}$ & P-Value \\
\hline Extremely likely & $7.4 \%$ & $4.2 \%$ & $1.5 \%$ & $13.8 \%$ & $7.0 \%$ & 0.323 \\
\hline Very likely & $20.6 \%$ & $15.5 \%$ & $26.5 \%$ & $21.3 \%$ & $20.9 \%$ & \\
\hline Somewhat likely & $30.9 \%$ & $38.0 \%$ & $32.4 \%$ & $23.8 \%$ & $31.0 \%$ & \\
\hline Not very likely & $26.5 \%$ & $28.2 \%$ & $26.5 \%$ & $27.5 \%$ & $27.2 \%$ & \\
\hline Not at all likely & $14.7 \%$ & $14.1 \%$ & $13.2 \%$ & $13.8 \%$ & $13.9 \%$ & \\
\hline
\end{tabular}

$* *$ Significant at the 0.05 level $\quad *$ Significant at the 0.10 level

\section{Media}

Question 18 is about the media and it asked which kind of media the responder use to find information about meat. The result shows significant differences. It appears that all generations use social media differently. The meat department and friends and family are the most important tools used in getting information about meat and both are word of mouth and not social media. 
Table 4-20: Which of the following do you use to find information about meat?

\begin{tabular}{|c|c|c|c|c|c|c|}
\hline & $\begin{array}{c}\text { Young } \\
\text { Millennials } \\
(\mathrm{N}=68)\end{array}$ & $\begin{array}{c}\text { Older } \\
\text { Millennials } \\
(\mathrm{N}=71)\end{array}$ & $\begin{array}{c}\text { Generation } \mathrm{X} \\
(\mathrm{N}=70)\end{array}$ & $\begin{array}{c}\text { Baby } \\
\text { Boomers } \\
(\mathrm{N}=79)\end{array}$ & $\begin{array}{c}\text { Total } \\
(\mathrm{N}=288)\end{array}$ & P-Value \\
\hline $\mathrm{B} \log \mathrm{s}$ & $8.7 \%$ & $18.3 \%$ & $15.7 \%$ & $2.5 \%$ & $11.0 \%$ & $0.008 * *$ \\
\hline Radio & $5.8 \%$ & $7.0 \%$ & $2.9 \%$ & $5.0 \%$ & $5.2 \%$ & 0.722 \\
\hline Google & $37.7 \%$ & $38.0 \%$ & $30.0 \%$ & $13.8 \%$ & $29.3 \%$ & $0.003 * *$ \\
\hline Twitter & $1.4 \%$ & $4.2 \%$ & $1.4 \%$ & & $1.7 \%$ & 0.252 \\
\hline Facebook & $14.5 \%$ & $9.9 \%$ & $7.1 \%$ & $2.5 \%$ & $8.3 \%$ & $0.061 *$ \\
\hline Print Newspapers & $15.9 \%$ & $18.3 \%$ & $21.4 \%$ & $33.8 \%$ & $22.8 \%$ & $0.042 * *$ \\
\hline QR Code & $2.9 \%$ & $4.2 \%$ & $2.9 \%$ & $1.3 \%$ & $2.8 \%$ & 0.74 \\
\hline Newspapers Online & $5.8 \%$ & $8.5 \%$ & $12.9 \%$ & $12.5 \%$ & $10.0 \%$ & 0.434 \\
\hline YouTube & $4.3 \%$ & $11.3 \%$ & $4.3 \%$ & $1.3 \%$ & $5.2 \%$ & $0.044 * *$ \\
\hline Food Web Sites & $27.5 \%$ & $26.8 \%$ & $31.4 \%$ & $15.0 \%$ & $24.8 \%$ & 0.103 \\
\hline Recipe Web Sites & $18.8 \%$ & $35.2 \%$ & $35.7 \%$ & $20.0 \%$ & $27.2 \%$ & $0.025 * *$ \\
\hline Cooking Shows & $17.4 \%$ & $36.6 \%$ & $28.6 \%$ & $25.0 \%$ & $26.9 \%$ & $0.077 *$ \\
\hline $\begin{array}{l}\text { Food Magazines } \\
\text { Online }\end{array}$ & $17.4 \%$ & $21.1 \%$ & $18.6 \%$ & $8.8 \%$ & $16.2 \%$ & 0.179 \\
\hline $\begin{array}{l}\text { The meat } \\
\text { department }\end{array}$ & $42.0 \%$ & $45.1 \%$ & $42.9 \%$ & $42.5 \%$ & $43.1 \%$ & 0.984 \\
\hline Friends and Family & $65.2 \%$ & $64.8 \%$ & $62.9 \%$ & $48.8 \%$ & $60.0 \%$ & 0.116 \\
\hline
\end{tabular}

** Significant at the 0.05 level

*Significant at the 0.10 level

Baby Boomer respondents' top three media use are printed newspaper, cooking shows, and recipe web sites. Generation xers respondents' top three media use are recipe web sites, food web sites, and Google. Older Millennial respondents' top three media usages are Google, cooking shows, and recipe web sites. Young millennial respondents' have very similar results as older millennials the results show the top three media usage are Google, Food web sites, and recipe web sites. It is clear that in order to reach different generations with information about meat, different media sources need to be used. 


\section{Demographics}

The earlier part of this chapter showed the result of the question 24 age amongst the generations. This part of demographics shows the results of whom those generations are.

Question 19 asked for the gender of the respondent. The result shows no significant difference across the generations.

Table 4-21: Gender

\begin{tabular}{|l|c|c|c|c|c|c|}
\hline & $\begin{array}{c}\text { Young } \\
\text { Millennials } \\
(\mathrm{N}=68)\end{array}$ & $\begin{array}{c}\text { Older Millennials } \\
(\mathrm{N}=71)\end{array}$ & $\begin{array}{c}\text { Generation X } \\
(\mathrm{N}=70)\end{array}$ & $\begin{array}{c}\text { Baby } \\
\text { Boomers } \\
(\mathrm{N}=79)\end{array}$ & $\begin{array}{c}\text { Total } \\
(\mathrm{N}=288)\end{array}$ & P-Value \\
\hline Female & $39.7 \%$ & $51.4 \%$ & $56.5 \%$ & $54.4 \%$ & $50.7 \%$ & 0.197 \\
\hline Male & $60.3 \%$ & $48.6 \%$ & $43.5 \%$ & $45.6 \%$ & $49.3 \%$ & \\
\hline
\end{tabular}

**Significant at the 0.05 level

*Significant at the 0.10 level

There is a significant difference between generations with respect to their marital status (table 4-20). Both baby boomers and generation Xers are more likely to be married. As both young and older millennials are more likely to be single.

Table 4-22: Martial Status

\begin{tabular}{|l|c|c|c|c|c|c|}
\hline & $\begin{array}{c}\text { Young } \\
\text { Millennials } \\
(\mathrm{N}=68)\end{array}$ & $\begin{array}{c}\text { Older } \\
\text { Millennials } \\
(\mathrm{N}=71)\end{array}$ & $\begin{array}{c}\text { Generation X } \\
(\mathrm{N}=70)\end{array}$ & $\begin{array}{c}\text { Baby } \\
\text { Boomers } \\
(\mathrm{N}=79)\end{array}$ & $\begin{array}{c}\text { Total } \\
(\mathrm{N}=288)\end{array}$ & P-Value \\
\hline Married & $7.2 \%$ & $36.6 \%$ & $69.1 \%$ & $73.8 \%$ & $47.6 \%$ & $0.000 * *$ \\
\hline $\begin{array}{l}\text { Living with a } \\
\text { partner }\end{array}$ & $7.2 \%$ & $21.1 \%$ & $7.4 \%$ & $7.5 \%$ & $10.8 \%$ & \\
\hline Single & $85.5 \%$ & $42.3 \%$ & $22.1 \%$ & $13.8 \%$ & $39.9 \%$ & \\
\hline Widowed & & & $1.5 \%$ & $5.0 \%$ & $1.7 \%$ & \\
\hline
\end{tabular}

**Significant at the 0.05 level *Significant at the 0.10 level 
In the table 4-23, generation Xers are more likely (60\%) to have children under 18 living at home. The majority of three generations young, older millennial, and baby boomers show that the majority does not have children living at home under 18 .

Table 4-23: Children under 18 living at home

\begin{tabular}{|c|c|c|c|c|c|c|}
\hline & $\begin{array}{c}\text { Young } \\
\text { Millennials } \\
(\mathrm{N}=68)\end{array}$ & $\begin{array}{c}\text { Older } \\
\text { Millennials } \\
(\mathrm{N}=71)\end{array}$ & $\begin{array}{c}\text { Generation X } \\
(\mathrm{N}=70)\end{array}$ & $\begin{array}{c}\text { Baby } \\
\text { Boomers } \\
(\mathrm{N}=79)\end{array}$ & $\begin{array}{c}\text { Total } \\
(\mathrm{N}=288)\end{array}$ & P-Value \\
\hline Yes & $2.9 \%$ & $27.9 \%$ & $60.0 \%$ & $15.4 \%$ & $25.8 \%$ & 0.000 \\
\hline No & $97.1 \%$ & $72.1 \%$ & $40.0 \%$ & $84.6 \%$ & $74.2 \%$ & \\
\hline
\end{tabular}

$* *$ Significant at the 0.05 level $\quad *$ Significant at the 0.10 level

Question 22 asked the respondents about the level of education completed. The older millennials show a high number of college graduates in the education area of $63.8 \%$. Besides that, there is a significant difference among the generations. Baby boomers' have a high number of college graduates of $50 \%$. The result is similar to Generation X of $52.9 \%$. The young millennials show a high number of some college of $46.3 \%$.

Table 4-24: Education

\begin{tabular}{|c|c|c|c|c|c|c|}
\hline & $\begin{array}{c}\text { Young } \\
\text { Millennials } \\
(\mathrm{N}=68)\end{array}$ & $\begin{array}{c}\text { Older } \\
\text { Millennials } \\
(\mathrm{N}=71)\end{array}$ & $\begin{array}{l}\text { Generation } \\
\mathrm{X} \quad(\mathrm{N}=70)\end{array}$ & $\begin{array}{c}\text { Baby } \\
\text { Boomers } \\
(\mathrm{N}=79) \\
\end{array}$ & $\begin{array}{c}\text { Total } \\
(\mathrm{N}=288)\end{array}$ & P-Value \\
\hline $\begin{array}{l}\text { Grade School or } \\
\text { Less }\end{array}$ & & $2.9 \%$ & & & $.7 \%$ & 0.001 \\
\hline Some High School & $1.5 \%$ & & & & $.4 \%$ & \\
\hline $\begin{array}{l}\text { High School } \\
\text { Graduate }\end{array}$ & $11.9 \%$ & $11.6 \%$ & $5.9 \%$ & $7.7 \%$ & $9.2 \%$ & \\
\hline Some College & $46.3 \%$ & $14.5 \%$ & $23.5 \%$ & $23.1 \%$ & $26.6 \%$ & \\
\hline College Graduate & $31.3 \%$ & $63.8 \%$ & $52.9 \%$ & $50.0 \%$ & $49.6 \%$ & \\
\hline Post Graduate Work & $9.0 \%$ & $7.2 \%$ & $17.6 \%$ & $19.2 \%$ & $13.5 \%$ & \\
\hline
\end{tabular}

With respect to their employment status (table 4-25), there is a significant difference between the generations. Both older millennials and generation xers have a high percentage (75.4\% and $76.1 \%$ respectively) of being employed full time. For baby 
boomers, they didn't have as high a percentage as older millennials and generation xers but they marked that employed full time is a high percent $56.8 \%$. Young millennials have a high number of employed, part time, which makes sense based on their age and staying in school.

Table 4-25: Employment

\begin{tabular}{|l|c|c|c|c|c|c|}
\hline & $\begin{array}{c}\text { Young } \\
\text { Millennials } \\
(\mathrm{N}=68)\end{array}$ & $\begin{array}{c}\text { Older } \\
\text { Millennials } \\
(\mathrm{N}=71)\end{array}$ & $\begin{array}{c}\text { Generation } \\
\mathrm{X} \\
(\mathrm{N}=70)\end{array}$ & $\begin{array}{c}\text { Baby } \\
\text { Boomers } \\
(\mathrm{N}=79)\end{array}$ & $\begin{array}{c}\text { Total } \\
(\mathrm{N}=288)\end{array}$ & P-Value \\
\hline Employed, Full Time & $40.0 \%$ & $75.4 \%$ & $76.1 \%$ & $56.8 \%$ & $62.2 \%$ & $0.000 * *$ \\
\hline Employed, Part Time & $41.5 \%$ & $18.8 \%$ & $13.4 \%$ & $10.8 \%$ & $20.7 \%$ & \\
\hline Not Employed/ Retired & $18.5 \%$ & $5.8 \%$ & $10.4 \%$ & $32.4 \%$ & $17.1 \%$ & \\
\hline
\end{tabular}

$* *$ Significant at the 0.05 level *Significant at the 0.10 level

There is no significant difference across the generations on location where they lived. However, San Luis Obispo has a high percent of $32.1 \%$ as total among all generations.

Table 4-26: Location

\begin{tabular}{|c|c|c|c|c|c|c|}
\hline & $\begin{array}{c}\text { Young } \\
\text { Millennials } \\
(\mathrm{N}=68)\end{array}$ & $\begin{array}{c}\text { Older } \\
\text { Millennials } \\
(\mathrm{N}=71)\end{array}$ & $\begin{array}{l}\text { Generation } \mathrm{X} \\
\quad(\mathrm{N}=70)\end{array}$ & $\begin{array}{c}\text { Baby } \\
\text { Boomers } \\
(\mathrm{N}=79)\end{array}$ & $\begin{array}{c}\text { Total } \\
(\mathrm{N}=288)\end{array}$ & P-Value \\
\hline San Luis Obispo & $49.3 \%$ & $26.8 \%$ & $27.1 \%$ & $26.3 \%$ & $32.1 \%$ & 0.122 \\
\hline Arroyo Grande & $7.2 \%$ & $9.9 \%$ & $12.9 \%$ & $11.3 \%$ & $10.3 \%$ & \\
\hline Avila Beach & $1.4 \%$ & $4.2 \%$ & & $2.5 \%$ & $2.1 \%$ & \\
\hline Morro Bay & $7.2 \%$ & $16.9 \%$ & $11.4 \%$ & $13.8 \%$ & $12.4 \%$ & \\
\hline Cambria & & & & $1.3 \%$ & $.3 \%$ & \\
\hline Cayucos & & & $4.3 \%$ & $3.8 \%$ & $2.1 \%$ & \\
\hline Pismo Beach & $1.4 \%$ & $4.2 \%$ & $2.9 \%$ & $3.8 \%$ & $3.1 \%$ & \\
\hline Grover Beach & $10.1 \%$ & $5.6 \%$ & $11.4 \%$ & $6.3 \%$ & $8.3 \%$ & \\
\hline Nipomo & & & & $5.0 \%$ & $1.4 \%$ & \\
\hline Atascadero & $4.3 \%$ & $5.6 \%$ & $2.9 \%$ & $1.3 \%$ & $3.4 \%$ & \\
\hline Paso Robles & $5.8 \%$ & $9.9 \%$ & $12.9 \%$ & $12.5 \%$ & $10.3 \%$ & \\
\hline Other & $13.0 \%$ & $16.9 \%$ & $14.3 \%$ & $12.5 \%$ & $14.1 \%$ & \\
\hline
\end{tabular}

There is significant difference between the generations on their income status.

About $44 \%$ of the generation X, $34 \%$ of the baby boomers, and $24 \%$ of the older 
millennials reported an annual income between $\$ 75,000$ - $\$ 149,999$. For the young

millennial, only $36.4 \%$ made less than $\$ 20,000$ a year.

Table 4-27: Income

\begin{tabular}{|l|c|c|c|c|c|c|}
\hline & $\begin{array}{c}\text { Young } \\
\text { Millennials } \\
(\mathrm{N}=68)\end{array}$ & $\begin{array}{c}\text { Older } \\
\text { Millennials } \\
(\mathrm{N}=71)\end{array}$ & $\begin{array}{c}\text { Generation X } \\
(\mathrm{N}=70)\end{array}$ & $\begin{array}{c}\text { Baby } \\
\text { Boomers } \\
(\mathrm{N}=79)\end{array}$ & $\begin{array}{c}\text { Total } \\
(\mathrm{N}=288)\end{array}$ & $\begin{array}{c}\text { P- } \\
\text { Value }\end{array}$ \\
\hline Under $\$ 20,0000$ & $36.4 \%$ & $2.9 \%$ & $1.5 \%$ & $1.4 \%$ & $10.3 \%$ & $0.000 * *$ \\
\hline$\$ 20,000$ to $\$ 24,999$ & $12.1 \%$ & $2.9 \%$ & $1.5 \%$ & $1.4 \%$ & $4.4 \%$ & \\
\hline$\$ 25,000$ to $\$ 29,999$ & $6.1 \%$ & $2.9 \%$ & $1.5 \%$ & $1.4 \%$ & $2.9 \%$ & \\
\hline$\$ 30,000$ to $\$ 34,999$ & $4.5 \%$ & $8.6 \%$ & $1.5 \%$ & $1.4 \%$ & $4.0 \%$ & \\
\hline$\$ 35,000$ to $\$ 39,999$ & $18.2 \%$ & $7.1 \%$ & $1.5 \%$ & $1.4 \%$ & $7.0 \%$ & \\
\hline$\$ 40,000$ to $\$ 49,999$ & $7.6 \%$ & $5.7 \%$ & $9.1 \%$ & $11.3 \%$ & $8.4 \%$ & \\
\hline$\$ 50,000$ to $\$ 59,999$ & $9.1 \%$ & $21.4 \%$ & $4.5 \%$ & $7.0 \%$ & $10.6 \%$ & \\
\hline$\$ 60,000$ to $\$ 74,999$ & $6.1 \%$ & $20.0 \%$ & $13.6 \%$ & $18.3 \%$ & $14.7 \%$ & \\
\hline$\$ 75,000$ to $\$ 149,999$ & & $24.3 \%$ & $43.9 \%$ & $33.8 \%$ & $25.6 \%$ & \\
\hline$\$ 150,000$ or more & & $4.3 \%$ & $21.2 \%$ & $22.5 \%$ & $12.1 \%$ & \\
\hline
\end{tabular}

**Significant at the 0.05 level

*Significant at the 0.10 level 


\section{CHAPTER 5}

\section{Summary and Conclusions}

\section{Summary}

A survey was developed to compare meat purchasing attitudes across generations. In the end, there were a total of 290 respondents that answered the survey in San Luis Obispo County. Each generational group had the same amount of respondents, which made it easier to compare the results. The young millennials totaled 70 respondents, older millennials totaled 72 respondents, generation xers with a total of 71 respondents, and baby boomers with a total of 82 respondents.

\section{Conclusions}

Four hypotheses were developed before the analysis of the responses from SurveyMonkey.

Hypothesis 1: There are significant differences in purchasing behaviors between generations who purchase meat.

Hypothesis 2: There are significant differences in purchasing behaviors between generations on the amount of money spent on meat. 
Hypothesis 3: There are significant differences in purchasing behaviors between generations who purchase local meat.

Hypothesis 4 : There are significant differences between young and older millennials in the factors that influence their decisions to purchase meat.

Hypothesis 5: There are significant differences in the factors that influence their decisions to purchase the meat between generations.

Results showed that there are no significant differences about generations with respect to their chicken consumption (Hypothesis 1). All the generations responded with above $90 \%$ consumption of chicken in the previous year. However, there is a significant difference for beef, pork, and other meat consumption among generations. Baby boomers show a high percentage of beef consumption (96.3\%) compared to other generations. Both Baby Boomers and Generation X consume more pork ( $80 \%$ and $81.4 \%$ respectively) than two other generations. Results provide evidence that supports the initial hypothesis.

The next hypothesis is related to the amount of money respondents spend on meat. It is assumed that there is a significant difference between generational purchases. The hypothesis is supported by the results reported in chapter four. In hypothesis one, it shows that there is a significant difference in the quantity purchased for beef, pork, and other meat, which makes sense that there is significant different on the amount of money spent on meat consumption.

The third hypothesis suggests that there are significant differences in purchasing behaviors between generations who purchase local meat. According to the results, there is 
no significant difference between generations who purchase local meat. However, there is a significant difference in purchasing local fruits, vegetables, and wine. They all have different levels of desirability to purchase local fruits, vegetables, and wine but all the generations show stronger desirability to purchase local fruits and vegetables over local meat with a total mean of 3.78 and 3.81 . The average mean for local meat desirability is 3.45 , which is average desirability to purchase. The conclusion is that there is no significant difference in purchasing local meat between the generations. The hypothesis null is rejected.

The fourth hypothesis focuses on the young and older millennials and which factors that influence their decision to purchase meat. Both young and older millennials agreed on the top two factors of good value for the money and no hormones added. Organic is one other factor that is favorable for older millennials but young millennials mark it as least desirable than all other factors. For older millennials the least desirable factor is local brand. The conclusion is that there are only a few factors that affect young and older millennials differently such as local brand and organic.

The last hypothesis (there is significant difference in the factors that influence meat purchasing behavior) failed to be rejected. There are only two factors that show significant differences across the generations being not fed animal by products and local brand.

Aside from all the generations' different lifestyles, cultures, and education, their attitudes are similar when it comes to meat purchasing. From meat consumption per year to the factors that influence their decision, their purchasing patterns are similar. In further 
research, it is possible that generations have different attitudes toward meat purchasing due to different regional cultures.

In conclusion, the results show the implications of establishing a new company whose plans are to start selling meat. The greatest gain in knowledge is knowing what consumers' most and least desirable factors are that influence their purchasing decisions.

The advice for the new company is to opt out of the organic practice because it is not important to consumers compared to all other factors. To help the company to improve the growth is to meet consumers' demand. It's important to understand what consumers' are looking for and what makes them buy meat products. The most desirable trait is having good value for the money. This is the number one reason to make the consumer want to by more meat product. The suggestion is to have a fair choice for quality of meat and the value for it. Rather than the grass fed meat that has low quality with high market value, it is not going to helps with growth because organic traits are consumers' least desirable factor. For the new local company that sells meat to the local market, it is most important to keep the focus on local even though a local brand have second least desirable. To improve the demand for a local brand is to educate what local means and what benefits there are for purchasing it. Not all consumers know what local means. Lastly, the image is not part of the survey but it is suggested that the company should show the images of the operation as to how they raise their livestock, how they are fed, and how they well they are taken care of. This can be done relatively inexpensively through a website, Facebook, and Google. 


\section{REFERENCES}

Babbie, Earl. (2009). The Practice of Social Research. 10 ${ }^{\text {th }}$ Edition. Belmont: Thomson Wadsworth.

Brewer, S. (2002). Consumer Attitudes: what they say and what they do. Fact Sheet, Pork Information Gateway.

Bureau of Labor Statistics. (2012) Consumer Expenditure Survey. Age of Reference Person. Retrieved from http://www.bls.gov/cex/2012/combined/age.pdf

Conner, D, Colasanti, K., Ross, R.B, and Smalley, S.B. (2010). Locally Grown Foods and Farmers Markets: consumer attitudes and behaviors. Journal of Sustainability. 2, 742-756.

Gilg, A. W., and Batterhill, M. (1998). Quality farm food in Europe. A possible alternative to the industrialised food market and to current agri-environmental policies. Lessons from France. Food Policy, 23(1), 25-40.

Grunert, K.G. (2006). Future trends and consumer lifestyles with regard to meat consumption. Meat Science. 74, 149-160.

Haley, M.M. (2001). Changing Consumer Demand for Meat: The U.S. Example, 19702000. Economic Research Service/USDA.

Higgs, J.D. 2000. Leaner meat: an overview of the compositional changes in red meat over the last 20 years and how these have been achieved. Food Science and Technology Today, 14, 22-26.

Hughner, R.S., McDonagh, P., Prothero, A., Shultz, C.J. and Stanton, J. 2007. Who are organic food consumers? A compilation and review of why people purchase organic food. Journal of Consumer Behavior. 6: 1-17.

Jefferies. (2012). "Rise of the Millennials and Aging of the Boomer Generation will mean 'Trouble in Aisle 5' for established food brands and traditional grocery stores." Alix Partners. Web.

Jolly, D. (1983). "Reasons for the decline in beef consumption." California Agriculture. May-June 1983. Web.

Journeys in Survey Research. (2011). "What is SPSS?” http://surveyresearch.weebly.com. 
Martinez, S., Hand, M., Newman, C., Pra, M. D., Pollack, S., Ralston, K., et al. (2010). Local Food System. ERS. Retrieved February 6, 2014, from http://www.ers.usda.gov/publications/err-economic-research-report/err97/report summary.aspx

Onken, K. A., Bernard, J. C., \& Pesek, J. D., Jr. (2011). Comparing willingness to pay for organic, natural, locally grown, and state marketing program promoted foods in the MidAtlantic region. In D. R. Just \& G. Blalock (Eds.), Agricultural and Resource Economics Review (Vol. 40, pp. 33-47): Northeastern Agricultural and Resource Economics Association.

Pew Research Center. (2010). "Millennials A Portrait of Generation Next." Pewsocialtrends.org.

Resurrecion, A.V.A (2003). Sensory aspects of consumer choices for meat and meat products. Meat Science, 66, 11-20.

Umberger, W. J., Smith, A. R., \& Thilmany McFadden, D. D. (2009). Does altruism play a Role in determining U.S. consumer preferences and willingness to pay for natural and regionally produced beef? [electronic resource]. Agribusiness, 25(2), 268-285. doi: http://dx.doi.org/10.1002/agr.20194

Voelkl, Kristine E. and Gerber, Susan B. (1999). Using SPSS for Windows Data Analysis and Graphics. Springer-Verlag New York, Inc.

Williams, K.C., and Page, R.A. (2011). Marketing to the Generations. Journal of Behavioral Studies in Business. Web. http://www.www.aabri.com/manuscripts/10575.pdf.

Wolf, Marianne M. (2009). AGB 405 Notes Labs. El Corral Publications.

Wolf, M., Spittler, A., \& Ahern, J. (2005). A Profile of Farmers' Market Consumers and the Perceived Advantages of Produce Sold at Farmers' Markets. Journal Of Food Distribution Research, 36(1), 192-201.

Worsley, A., Wang, W.C., and Hunter, W. (2010). Baby boomers' food shopping habits. Relationships with demographics and personal values. Appetite, 55, 466-472. 


\section{APPENDIX A}

1.

1. Which of the following meat products have you purchased for consumption at home in the last year?
$\square$ chicken
$\square$ Pork
I do not buy meat
Beef
Other Meat

Terminate if the respondent does not eat meat.

2. Have you ever purchased any of the following Cal Poly brand food or wine products? (mark all that apply)

$\square$ Frults and/or Vegetables

$\square$ ice Cream

$\square$ Wine

$\square$ Cheese

Other Cal Poly Food Products

$\square$ Meats

I have not purchased any Cal Poly brand food or wine products.

3. Even if you have not purchased Cal Poly food or wine products, based on your experience or perceptions, how would you rate Cal Poly brand food and wine products on the following?

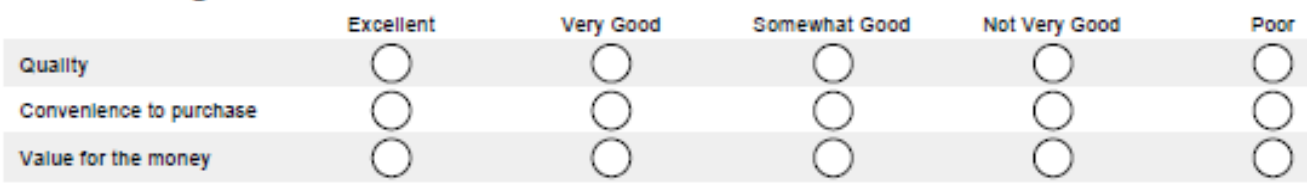

4. Over the past year, where have you purchased your meat products?

$\square$ Chain grocery store (Albertsons, Ralphs, Vons)

$\square$ Trader Joe's

$\square$ Farmer's Market

$\square$ Costco

$\square$ Fresh \& Easy

$\square$ New Fronters

$\square$ Restaurant

$\square$ Spencer's

Cal Poly's Meat Processing Center

Other (please specily)

|

5. Approximately how much money do you spend in a typical month on meat products? 


\begin{tabular}{|c|c|c|c|c|}
\hline \multicolumn{5}{|c|}{$\begin{array}{l}\text { 6. Please think of the last hundred dollars you spent on meat, how much of it was spent on } \\
\text { the following? }\end{array}$} \\
\hline \multicolumn{5}{|l|}{ chlcken } \\
\hline \multicolumn{5}{|l|}{ Beet } \\
\hline \multicolumn{5}{|l|}{ Pork } \\
\hline \multicolumn{5}{|l|}{ other } \\
\hline \multicolumn{5}{|c|}{$\begin{array}{l}\text { 7. Of the number of times that you serve beef in a month, what percent is ground beef and } \\
\text { what percent is steak/roasts? Example } \mathbf{5 0} \% \text { Ground Beef, } \mathbf{5 0} \% \text { Steaks/Roast or } \mathbf{1 0} \%\end{array}$} \\
\hline \multicolumn{5}{|c|}{ Ground Beef, $90 \%$ Steaks/Roast } \\
\hline \multicolumn{5}{|c|}{ Ground beet $\quad \mid$} \\
\hline \multicolumn{5}{|l|}{ Steaks/ Roasts } \\
\hline \multicolumn{5}{|c|}{$\begin{array}{l}\text { 8. The following is a list of features people may look for when purchasing meat. Please } \\
\text { indicate the desirability of each feature to you when you purchase meat. }\end{array}$} \\
\hline \multicolumn{5}{|c|}{ Extremely Desirable, Very Desirable, Somewhat Desirable, Slightly Desirable, Not At All } \\
\hline \multicolumn{5}{|c|}{ Desirable } \\
\hline & Very desirable & $\begin{array}{c}\text { Somewhat } \\
\text { desirable }\end{array}$ & $\begin{array}{l}\text { Not very } \\
\text { desirable }\end{array}$ & $\begin{array}{l}\text { Not desirable at } \\
\text { all }\end{array}$ \\
\hline \multicolumn{5}{|l|}{ No hormones added } \\
\hline \multicolumn{5}{|l|}{ Good value for the money } \\
\hline \multicolumn{5}{|l|}{ Organle } \\
\hline \multicolumn{5}{|l|}{ Not treated with antiblotics } \\
\hline \multicolumn{5}{|l|}{ Natural } \\
\hline \multicolumn{5}{|l|}{ Local brand } \\
\hline \multicolumn{5}{|l|}{ Not fed anlmal by-products } \\
\hline \multicolumn{5}{|c|}{ 9. Are you currently involved in local food initiatives (eg: CSA, farmer's markets, etc.)? } \\
\hline \multicolumn{5}{|c|}{$\bigcirc_{\text {Yes }} \bigcirc^{\text {No }}$} \\
\hline \multicolumn{5}{|c|}{ 10. When thinking about purchasing local food products, how do you define local? } \\
\hline \multicolumn{5}{|c|}{$\bigcirc<10$ Mlles $\quad \bigcirc<50$ Miles $\quad$ 100+ Mlles } \\
\hline \multicolumn{5}{|l|}{ - 30 Miles } \\
\hline \multicolumn{5}{|c|}{ 11. When thinking about purchasing local food products, do you define local to be from... } \\
\hline \multicolumn{5}{|c|}{$\bigcirc$ Your home town/clty $\quad \bigcirc$ Your state $\bigcirc$ us } \\
\hline \multicolumn{5}{|l|}{ Your county } \\
\hline \multicolumn{5}{|c|}{ 12. What means more to you when deciding what local is? } \\
\hline Mileage (set dlstanc & Locallty (Clty, C & :ounty, or State) & & \\
\hline
\end{tabular}




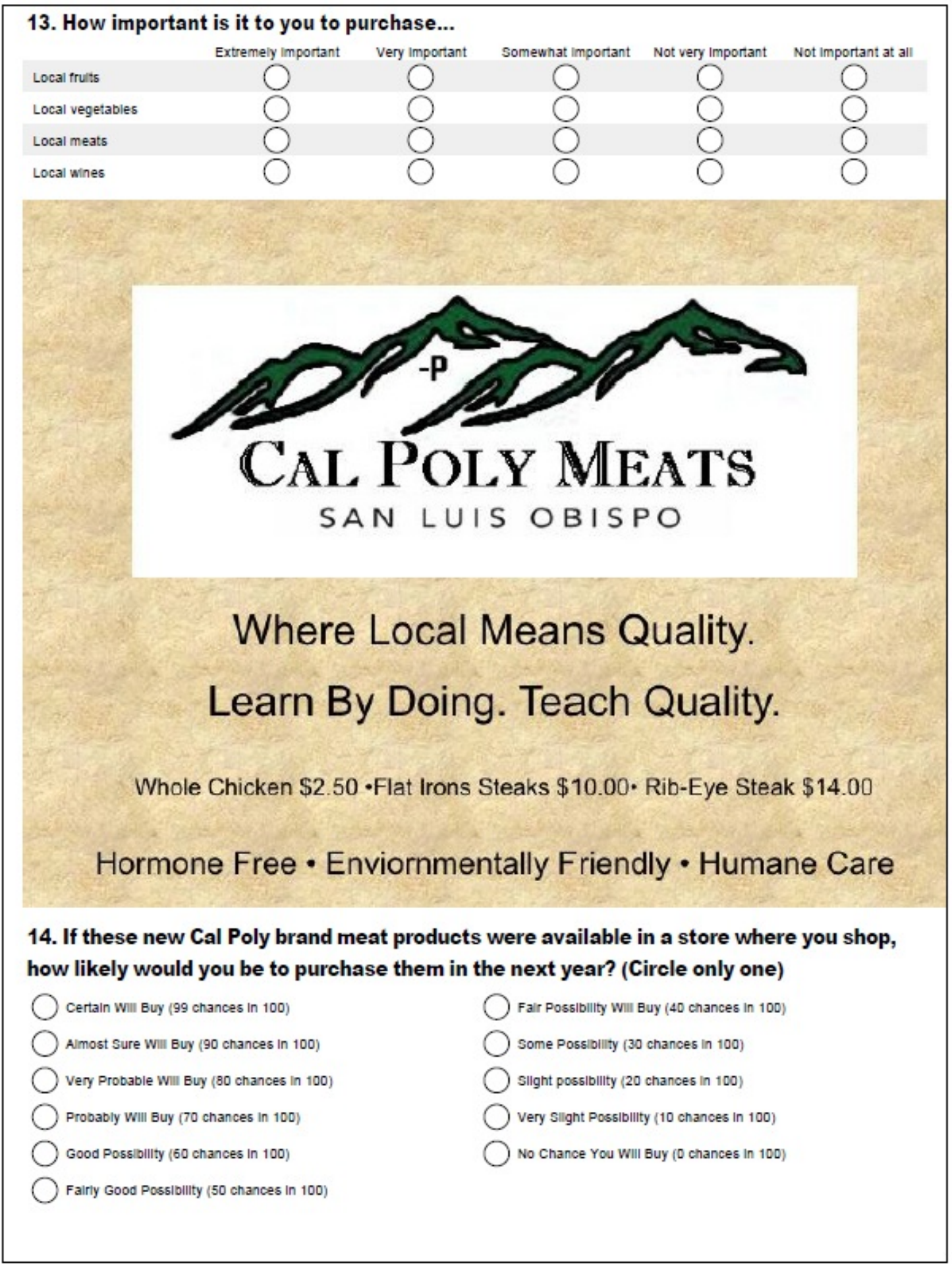


15. Is the price of these products?

Too high $\bigcirc$ Too low

16. How likely are you to purchase a Cal Poly meat product at a local farmers' market?

$\bigcirc$ Extremely Ilkely $\bigcirc$ very Ilkely $\bigcirc$ somewhat Ilkely $\bigcirc$ Not very Ilkely

17. How likely are you to go to the Cal Poly campus to purchase Cal Poly meats, if there was free parking available?

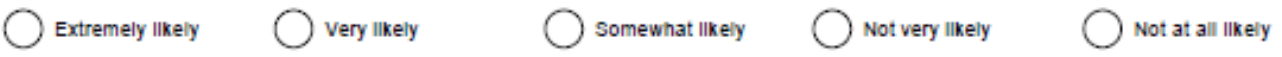

18. Which of the following do you use to find information about meat? (Choose all that apply.)

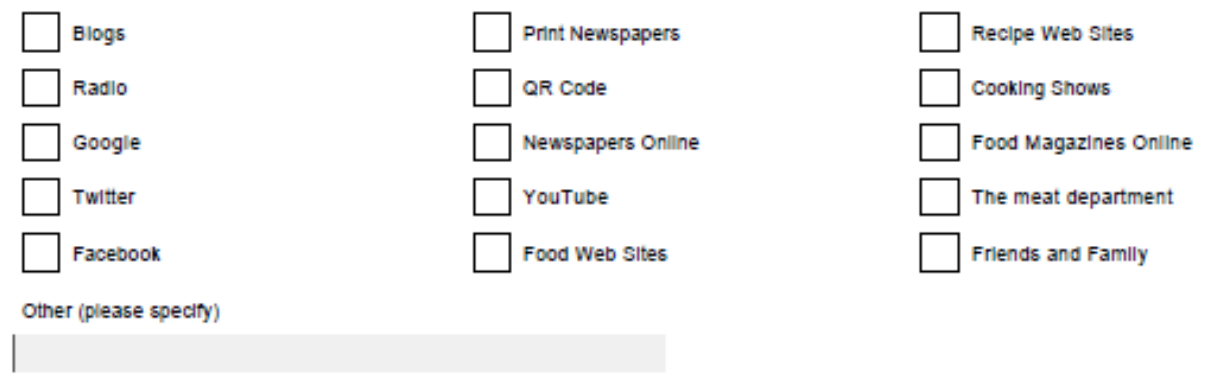

19. Are you?

Female $\bigcirc$ male

20. Are you...

$\bigcirc$ Marrled $\bigcirc$ uving with a parther $\bigcirc$ single $\quad \bigcirc$ widowed

21. Do you have any children under 18 living at home? (Circle only one)

$\bigcirc$ yes

№

22. Please tell me the level of education you have completed. (Circle only one)
Grade school or Less
Hign school Graduate
college Graduate
Some High School
Some college
$\bigcirc$ Post Graduate Work

23. Are you employed?
Employed, Full TIme
(Employed, Part Time
Not Employed/ Retired 
24. Which of the following ranges describes your age?
18 to 20
30 to 32
45 to 49
${ }_{21 \text { to } 24}$
33 to 34
50 to 54
25 to 27
35 to 39
55 to 64
28 to 29
40 to 44
65+ years

25. Where do you live?
San Luls Oblspo
cambria
Nipomo
Arroyo Grande
cayucos
other
Avlla Beach
Plsmo Beach
Morro Bay
Grover Beach

26. Which of the following ranges describes your household income before taxes?
under 520,000
( $\$ 35,000$ to $\$ 39,999$
○ $\$ 20,000$ to $\$ 24,999$
( 540,000 to 549,999
$\$ 25,000$ to $\$ 29,999$
S50,000 to 559,999
( $\$ 30,000$ to $\$ 34,999$
( 560,000 to $\$ 74,999$

( $\$ 75,000$ to $\$ 149,999$

\$ $\$ 150,000$ or more

27. Thank you! Please provide your email address so my professor can confirm that I completed this survey.

\section{ID Number}

ID 